\title{
Erratum to: Crystal preferred orientations of olivine, orthopyroxene, serpentine, chlorite, and amphibole, and implications for seismic anisotropy in subduction zones: a review
}

\author{
Haemyeong Jung* \\ Tectonophysics Laboratory, School of Earth and Environmental Sciences, Seoul National University, Seoul 08826, Republic of Korea
}

Erratum to: Geosciences Journal, 2017, 21, 985-1011, DOI 10.1007/s12303-017-0045-1

There are errors in the article entitled "Crystal preferred orientations of olivine, orthopyroxene, serpentine, chlorite, and amphibole, and implications for seismic anisotropy in subduction zones: a review” by Haemyeong Jung, which appeared on pages 985-1011 of the December issue in 2017. The author has provided a corrected article which is attached at the end of this erratum.

\footnotetext{
*Corresponding author:

Haemyeong Jung

Tectonophysics Laboratory, School of Earth and Environmental Sciences, Seoul National University, Seoul 08826, Republic of Korea Tel: +82-2-880-6733, Fax: +82-2-871-3269, E-mail: hjung@snu.ac.kr

The online version of the original article can be found under DOI 10.1007/s12303-017-0045-1
}

(C)The Association of Korean Geoscience Societies and Springer 2018 


\title{
Crystal preferred orientations of olivine, orthopyroxene, serpentine, chlorite, and amphibole, and implications for seismic anisotropy in subduction zones: a review
}

\author{
Haemyeong Jung* \\ Tectonophysics Laboratory, School of Earth and Environmental Sciences, Seoul National University, Seoul 08826, Republic of Korea
}

\begin{abstract}
This study provides a comprehensive review of the crystal preferred orientation (CPO) of olivine and orthopyroxene in the upper mantle, and of several hydrous minerals in the mantle wedge and at the slab-mantle interface. It discusses the seismic anisotropy of those minerals. Water-induced CPOs of olivine produced by previous experimental studies under high pressure and temperature conditions were found in many natural rocks. It is emphasized that the strong CPOs of hydrous minerals such as serpentine, chlorite, and amphibole, play an important role in interpreting the anomalously strong seismic anisotropy observed in subduction zones.
\end{abstract}

Key words: crystal preferred orientation, olivine, orthopyroxene, serpentine, chlorite, amphibole, seismic anisotropy

Manuscript received June 17, 2017; Manuscript accepted September 27, 2017

\section{INTRODUCTION}

Rocks inside the Earth's crust and mantle are deformed under differential stress at high pressure and temperature conditions, and those in the deep interior go through plastic deformation. The minerals constituting rocks are deformed and elongated, forming a crystal preferred orientation (CPO) or a lattice preferred orientation (LPO). If a mineral is elastically very anisotropic, the $\mathrm{CPO}$ of its aggregates can cause a significant seismic anisotropy in the crust and the mantle. Seismic anisotropy has been observed worldwide in the Earth's interior (Fig. 1) and can provide important information for understanding the evolution of the upper mantle, mantle flow pattern, mantle dynamics, and tectonics (Hess, 1964; Nicolas and Christensen, 1987; Silver, 1996; Ben Ismail and Mainprice, 1998; Savage, 1999; Jung and Karato, 2001; Smith et al., 2001; Jung et al., 2006; Mainprice, 2007; Karato et al., 2008; Long and Silver, 2008; Long and Silver, 2009; Di Leo et al., 2012; Jung, 2012; Long, 2013; Tommasi and Vauchez, 2015; Skemer and Hansen, 2016; Zhao et al., 2016). Therefore,

\section{*Corresponding author:}

Haemyeong Jung

Tectonophysics Laboratory, School of Earth and Environmental Sciences, Seoul National University, Seoul 08826, Republic of Korea Tel: +82-2-880-6733, Fax: +82-2-871-3269, E-mail: hjung@snu.ac.kr

(C)The Association of Korean Geoscience Societies and Springer 2017 studying the CPO of elastically anisotropic minerals that are dominant in the crust and the upper mantle is essential.

In the upper mantle, the dominant minerals inside rocks are olivine and orthopyroxene (Fig. 2a). Olivine is the most abundant mineral and is elastically anisotropic (Birch, 1960; Verma, 1960; Abramson et al., 1997) (Table 1). The CPO of olivine is key to understanding the seismic anisotropy and flow pattern of the upper mantle (Hess, 1964; Nicolas and Christensen, 1987; Ben Ismail and Mainprice, 1998; Jung et al., 2006; Karato et al., 2008; Cao et al., 2015; Michibayashi et al., 2016; Cao et al., 2017). In the mantle wedge and at the slab-mantle interface, hydrous minerals such as serpentine, chlorite, and amphibole (Figs. 2bd) can form from the fluids generated by the dehydration of hydrous minerals in the subducting slab (Ulmer and Trommsdorff, 1995; Peacock and Hyndman, 1999; Pawley, 2003; Fumagalli and Poli, 2005; van Keken et al., 2011). Many of hydrous minerals such as chlorite, amphibole, and serpentine can be formed after olivine meets water during exhumation in the mantle wedge and at the interface between slab and mantle wedge. Those hydrous minerals are known to be stable at a wide range of pressure-temperature conditions in subdution zone (Schimidt and Poli, 1998; Ulmer and Trommsdorf, 1995; Fumagali and Poli, 2005) (Fig. 3). Those hydrous minerals are also known as elastically anisotropic minerals (Aleksandrov and Ryzhova, 1961a; Mainprice and Ildefonse, 2009; Bezacier et al., 2010; Mookherjee 


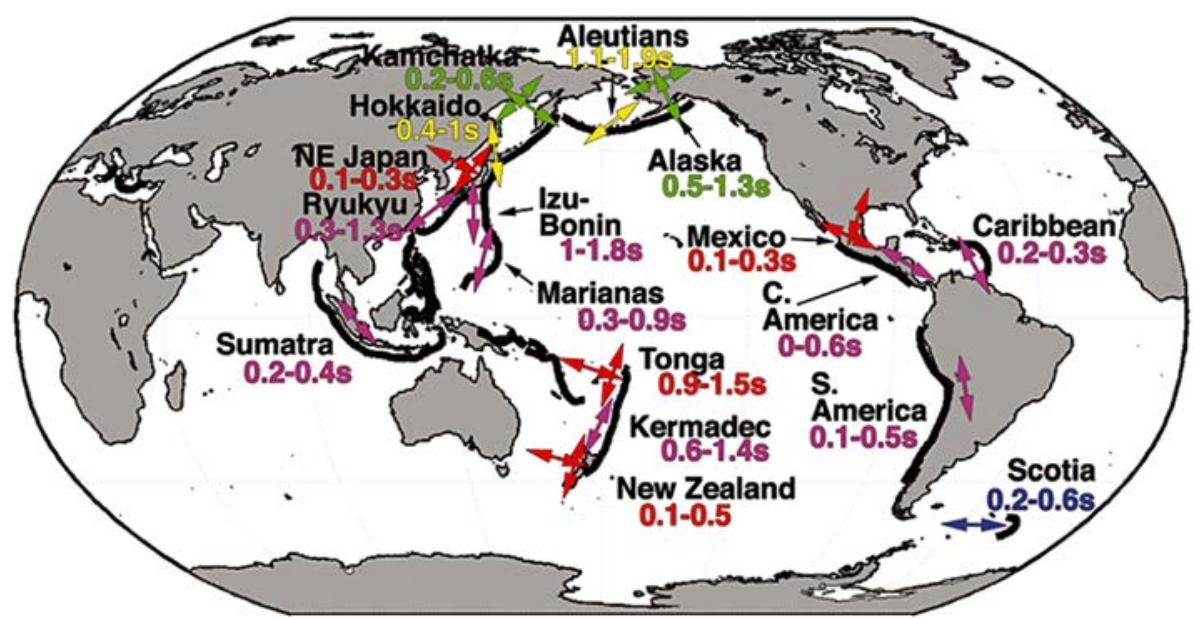

Fig. 1. Examples of seismic anisotropy observed worldwide. This figure shows a summary map of mantle wedge splitting of S-waves (Long and Wirth, 2013). Arrows indicate the first-order patterns in average fast direction; where multiple arrows are present, this indicates a spatial transition in observed orientation $(\phi)$. Arrows are color coded by fast direction observations; magenta arrows indicate dominantly trench-parallel $\phi$, blue arrows indicate dominantly trench-perpendicular $\phi$, yellow arrows indicate complex and variable $\phi$, red arrows indicate a transition from trench-parallel $\phi$ close to the trench to trench-perpendicular $\phi$ farther away, and green arrows indicate the opposite transition (from trench-perpendicular $\phi$ close to the trench to trench-parallel $\phi$ farther away). Beneath the name of each subduction zone, the range of observed delay times is indicated.

Table 1. Seismic (elastic) anisotropy of olivine and orthopyroxene (opx)

\begin{tabular}{|c|c|c|c|c|c|}
\hline \multirow{2}{*}{ Mineral } & \multicolumn{2}{|c|}{ Single crystal } & \multicolumn{2}{|c|}{ Poly crystal } & \multirow{2}{*}{ Reference } \\
\hline & $\mathrm{AVp}(\%)$ & $\max$. AVs (\%) & $\operatorname{AVp}(\%)$ & $\max$. AVs (\%) & \\
\hline \multirow{19}{*}{ Olivine (forsterite) } & 23.8 & 16.0 & & & Mainprice $(2007)^{(\mathrm{a})}$ \\
\hline & & & $4.9-11.1$ & $4.9-7.4$ & Jung and Karato $(2001)^{(\mathrm{a})}$ \\
\hline & & & $8.3-13.3$ & $5.3-9.3$ & Michibayashi et al. (2006) ${ }^{(a)}$ \\
\hline & & & $2.7-6.0$ & $1.8-4.8$ & Katayama and Karato $(2006)^{(\mathrm{a})}$ \\
\hline & & & 2.6 & 2.9 & Skemer et al. $(2006)^{(a)}$ \\
\hline & & & 12.0 & $7.0-10.4$ & Hidas et al. $(2007)^{(\mathrm{a})}$ \\
\hline & & & $4.5-9.8$ & $3.2-7.0$ & Tasaka et al. $(2008)^{(a)}$ \\
\hline & & & $7.8-13.6$ & $5.4-8.2$ & Jung et al. $(2009 a)^{(a)}$ \\
\hline & & & $3.2-7.2$ & $2.2-5.5$ & Jung $(2009)^{(a)}$ \\
\hline & & & $1.8-7.3$ & $2.2-5.5$ & Ohuchi et al. (2011) (a) \\
\hline & & & $6.1-8.6$ & $3.9-5.6$ & Michibayashi et al. (2012)(a) \\
\hline & & & $2.7-5.9$ & $2.5-5.0$ & Jung et al. $(2013)^{(a)}$ \\
\hline & & & $8.8-8.9$ & $5.3-5.7$ & Park et al. $(2014)^{(\mathrm{a})}$ \\
\hline & & & $1.2-3.6$ & $2.1-3.7$ & Watanabe et al. $(2014)^{(\mathrm{a})}$ \\
\hline & & & $2.2-11.6$ & $1.9-7.5$ & Park and Jung $(2015)^{(\mathrm{a})}$ \\
\hline & & & $1.8-3.8$ & $1.7-2.7$ & Kim and Jung (2015) ${ }^{(a)}$ \\
\hline & & & $5.2-9.1$ & $8.4-8.6$ & Boneh et al. $(2015)^{(a)}$ \\
\hline & & & $11.0-13.9$ & $10.5-14.2$ & Lee and Jung $(2015)^{(\mathrm{a})}$ \\
\hline & & & $1.8-7.5$ & $1.1-5.2$ & Kang and Jung (2017) $)^{(\mathrm{a})}$ \\
\hline \multirow{5}{*}{ Opx (enstatite) } & 13.7 & 17.6 & & & Mainprice $(2007)^{(b)}$ \\
\hline & & & 2.9 & 2.7 & Skemer et al. $(2006)^{(\mathrm{b})}$ \\
\hline & & & $1.8-5.9$ & $2.4-4.0$ & Jung et al. $(2010)^{(b)}$ \\
\hline & & & 3.4 & 3.9 & Jung et al. $(2013)^{(b)}$ \\
\hline & & & $1.2-2.3$ & $1.5-2.5$ & Park and Jung (2015) $)^{(\mathrm{b})}$ \\
\hline
\end{tabular}

AVp: anisotropy of P-wave velocity. $\mathrm{AVp}=100(\%) \times\left[\left(\mathrm{Vp}_{\max }-\mathrm{Vp}_{\min }\right) /\left(0.5 \times\left(\mathrm{Vp}_{\max }+\mathrm{Vp}_{\min }\right)\right)\right]$, where $\mathrm{Vp}_{\max }$ is the maximum $\mathrm{P}$-wave velocity and $\mathrm{Vp}_{\min }$ is the minimum P-wave velocity (Birch, 1960).

AVs: anisotropy of S-wave velocity. AVs $=100(\%) \times[(\mathrm{Vs} 1-\mathrm{Vs} 2) /(0.5 \times(\mathrm{Vs} 1+\mathrm{Vs} 2))]$, where Vs1 is the fast S-wave velocity and Vs2 is the slow S-wave velocity.

(a) Elastic constants of olivine(forsterite) from Abramson et al. (1997) were used.

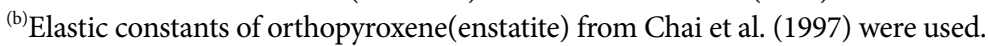



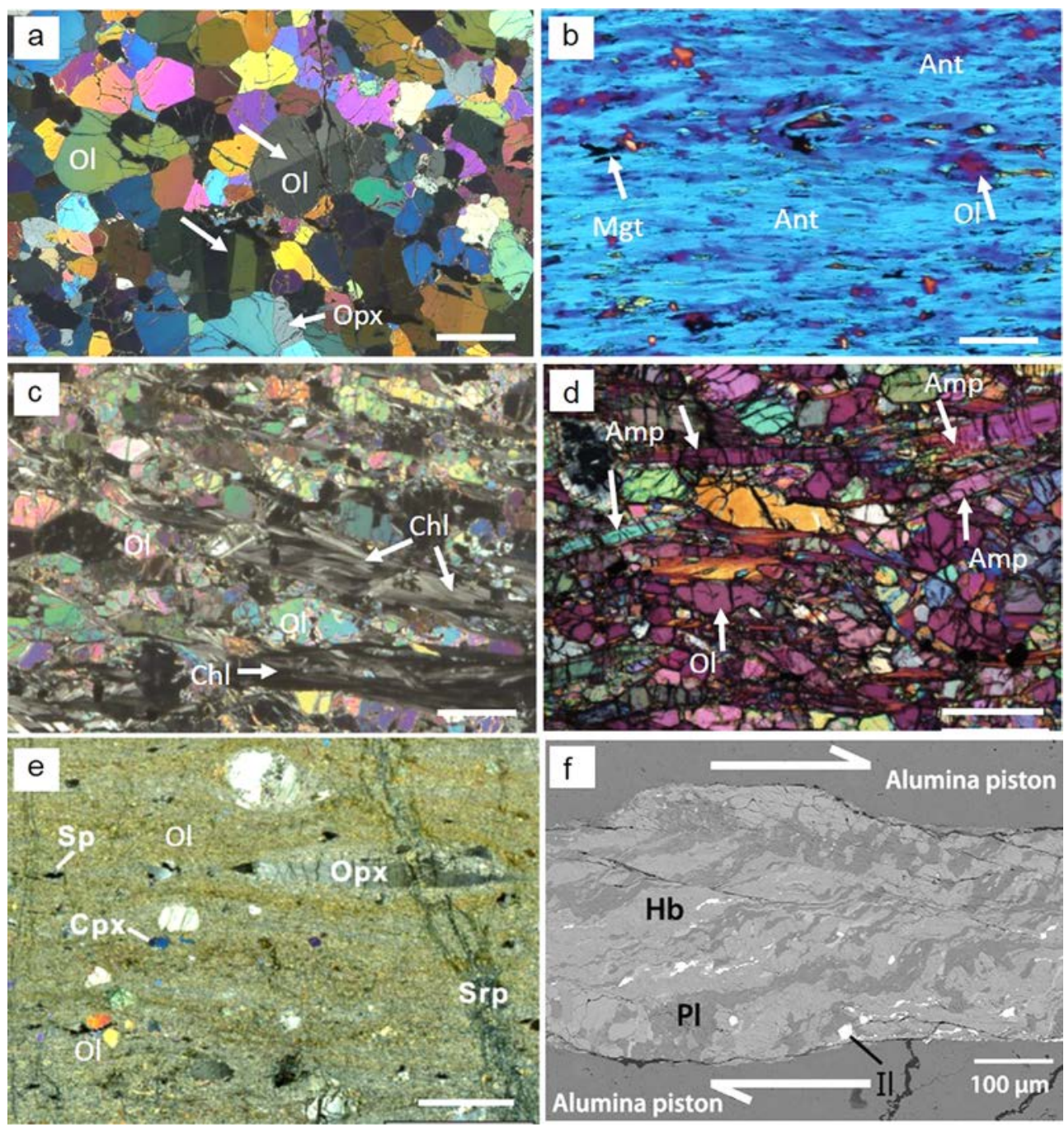

Fig. 2. Optical photomicrographs showing deformation microstructures of natural rocks (a-e) and an experimental sample (f). (a) Mantle xenolith (SVF-04) from Svalbard, Arctic showing olivine and orthopyroxene (Jung et al., 2009a). White arrows indicate Kink bands in olivine. Scale bar represents $2 \mathrm{~mm}$. (b) Serpentinite (VM3) from Val Malenco, Italy (Jung, 2011). Scale bar represents $0.2 \mathrm{~mm}$. (c) Chlorite peridotite (436) from Amklovdalen, SW Norway (Kim and Jung, 2015). Scale bar represents $1 \mathrm{~mm}$. (d) Amphibole peridotite from Bjorkedalen, SW Norway (Kang and Jung, submitted). Scale bar represents $0.5 \mathrm{~mm}$. (e) Yugu peridotite (YG-10) showing ultramylonite texture in Yugu, South Korea (Park and Jung, 2017). Scale bar represents $3 \mathrm{~mm}$. (f) A back-scattered electron image of a deformed amphibolite at a high pressure of $1 \mathrm{GPa}$ and temperature of $600{ }^{\circ} \mathrm{C}$ (Ko and Jung, 2015). Arrows show the sense of shear. Ol: olivine, Opx: orthopyroxene, Ant: antigorite, Mgt: magnetite, Chl: chlorite, Amp: amphibole, Sp: spinel, Cpx: clinopyroxene, Srp: serpentine, Hb: hornblende, Pl: plagioclase, and II: ilmenite.

and Mainprice, 2014) (Table 2); their CPOs are important for interpreting seismic anisotropy in many subduction zones (Katayama et al., 2009; Jung, 2011; Brownlee et al., 2013; Morales et al., 2013; Kim and Jung, 2015; Ko and Jung, 2015; Nagaya et al., 2016; Kang and Jung, submitted). In addition, one of the important minerals in the middle and lower crust is amphibole, which is also elastically anisotropic (Aleksandrov and Ryzhova, 1961a; Siegesmund et al., 1989; Weiss et al., 1999; Kaczmarek and Tommasi, 2011; Lloyd et al., 2011; Ji et al., 2013; Ko and Jung, 2015; Brown and Abramson, 2016; Almqvist and Mainprice, 2017). A recent experimental study under simple shear at high pressure and temperature showed that the CPO of amphibole (hornblende) might cause large seismic anisotropy (Ko and
Jung, 2015). Amphibole and chlorite in hydrated peridotites in the lower part of the mantle wedge also play a key role in the interpretation of seismic anisotropy in subduction zones (Kim and Jung, 2015; Kang and Jung, submitted).

This work provides a comprehensive review of the experimental studies on the CPO of olivine first. The effect of water, stress, temperature, pressure, shear strain, and deformation history on the CPO of olivine is presented along with the recent findings on the CPO of olivine in natural rocks. Next, the CPOs of orthopyroxene and serpentine are described, followed by a review of the recent advances in the study of the CPO of hydrous minerals including chlorite and hornblende. Finally, geophysical implications of the results of the recent studies on the CPOs of hydrous minerals 
Table 2. Seismic (elastic) anisotropy of hydrous minerals.

\begin{tabular}{|c|c|c|c|c|c|}
\hline \multirow{2}{*}{ Mineral } & \multicolumn{2}{|c|}{ Single crystal } & \multicolumn{2}{|c|}{ Poly crystal } & \multirow{2}{*}{ Reference } \\
\hline & $\mathrm{AVp}(\%)$ & $\max . \mathrm{AVs}(\%)$ & $\mathrm{AVp}(\%)$ & $\max . \mathrm{AVs}(\%)$ & \\
\hline \multirow{11}{*}{ Serpentine (antigorite) } & 71.2 & 67.6 & & & Mainprice and Ildefonse (2009) ${ }^{(\mathrm{a})}$ \\
\hline & 46.0 & 66.5 & & & Bezacier et al. $(2010)^{(\mathrm{b})}$ \\
\hline & & & $38.4-46.3$ & $24.2-32.4$ & Katayama et al. (2009) $)^{(\mathfrak{c})}$ \\
\hline & & & $10.4-31.3$ & $8.9-36.0$ & Hirauchi et al. $(2010)^{(\mathrm{b})}$ \\
\hline & & & 36.8 & 50.5 & Bezacier et al. $(2010)^{(\mathrm{b})}$ \\
\hline & & & 32.9 & 31.0 & Soda and Takagi (2010) ${ }^{(\mathrm{b})}$ \\
\hline & & & $23.6-31.4$ & $22.8-36.5$ & Jung $(2011)^{(b)}$ \\
\hline & & & $7.6-8.2$ & $14.0-36.2$ & Nishii et al. $(2011)^{(\mathrm{b})}$ \\
\hline & & & $5.7-27.6$ & $4.9-33.2$ & Brownlee et al. $(2013)^{(\mathrm{b})}$ \\
\hline & & & $13.9-25.7$ & $15.0-24.0$ & Watanabe et al. $(2014)^{(\mathrm{b})}$ \\
\hline & & & 34.2 & - & Nagaya et al. $(2016)^{(b)}$ \\
\hline \multirow{5}{*}{ Chlorite (clinochlore) } & 35.5 & 76.2 & & & Mainprice and Ildefonse (2009) ${ }^{(\mathrm{d})}$ \\
\hline & 35.5 & 76.2 & & & Kim and Jung $(2015)^{(\mathrm{d})}$ \\
\hline & & & $14.9-21.1$ & $14.5-31.7$ & Kim and Jung $(2015)^{(\mathrm{d})}$ \\
\hline & & & $10.3-15.2$ & $10.6-22.8$ & Kim and Jung $(2015)^{(\mathrm{e})}$ \\
\hline & & & $22.3-25.2$ & $31.6-46.2$ & Kang and Jung $(2017)^{(\mathrm{d})}$ \\
\hline \multirow{14}{*}{ Amphibole (hornblende) } & 27.2 & - & & & Kitamura $(2006)^{(\mathrm{f})}$ \\
\hline & 27.1 & 30.7 & & & Mainprice and Ildefonse $(2009)^{(\mathrm{f})}$ \\
\hline & 27.1 & 30.7 & & & Lloyd et al. $(2011)^{(\mathrm{f})}$ \\
\hline & 27.1 & 30.7 & & & Ko and Jung $(2015)^{(\mathrm{f})}$ \\
\hline & & & $9.5-11.1$ & $7.0-8.0$ & Siegesmund and Vollbrecht $(1991)^{(\mathrm{g})}$ \\
\hline & & & 11.4 & - & Barruol and Kern $(1996)^{(\mathrm{f}),(\mathrm{g})}$ \\
\hline & & & $3.2-7.7$ & - & Kitamura $(2006)^{(\mathrm{f}),(\mathrm{g})}$ \\
\hline & & & $3.6-6.0$ & $3.8-6.9$ & Tatham et al. $(2008)^{(\mathrm{f},(\mathrm{g})}$ \\
\hline & & & $7.5-14.0$ & $4.2-8.5$ & Ji et al. $(2013)^{(\mathrm{g}),(\mathrm{h})}$ \\
\hline & & & $10.2-13.5$ & $6.9-11.2$ & Jung et al. $(2014 a)^{(f)}$ \\
\hline & & & $9.0-14.6$ & $7.6-12.1$ & Ko and Jung $(2015)^{(\mathrm{f})}$ \\
\hline & & & $5.7-14.0$ & $4.1-8.5$ & Ji et al. $(2015)^{(\mathrm{g})(\mathrm{i})}$ \\
\hline & & & 11.4 & 6.9 & Lamarque et al. $(2016)^{(\mathrm{f})}$ \\
\hline & & & $10.0-15.2$ & $7.5-11.9$ & Kang and Jung $(2017)^{(\mathrm{f})}$ \\
\hline
\end{tabular}

AVp: anisotropy of P-wave velocity. $\mathrm{AVp}=100(\%) \times\left[\left(\mathrm{Vp}_{\max }-\mathrm{Vp}_{\min }\right) /\left(0.5 \times\left(\mathrm{Vp}_{\max }+\mathrm{Vp}_{\min }\right)\right)\right]$, where $\mathrm{Vp}_{\max }$ is the maximum $\mathrm{P}$-wave velocity and $\mathrm{Vp}_{\mathrm{min}}$ is the minimum P-wave velocity (Birch, 1960).

AVs: anisotropy of S-wave velocity. AVs $=100(\%) \times[(\mathrm{Vs} 1-\mathrm{Vs} 2) /(0.5 \times(\mathrm{Vs} 1+\mathrm{Vs} 2))]$, where Vs1 is the fast S-wave velocity and Vs2 is the slow S-wave velocity.

${ }^{(a)}$ Elastic constants of serpentine (antigorite) from Pellenq et al. (submitted) were used.

(b) Elastic constants of serpentine (antigorite) from Bezacier et al. (2010) were used.

${ }^{(c)}$ Elastic constants of serpentine (lizardite) from Auzende et al. (2006).

(d) Elastic constants of chlorite (clinochlore) from Alexandrov and Ryzhova (1961b).

${ }^{(e)}$ Elastic constants of chlorite (clinochlore) from Mookherjee and Mainprice (2014).

${ }^{(f)}$ Elastic constants of amphibole (hornblende) from Alexandrov and Ryzhova (1961a).

${ }^{(\mathrm{g})}$ Seismic anisotropy of whole rock, amphibolite.

(h) Elastic constants of amphibole(hornblende) from Hearmon (1984).

${ }^{(i)}$ Elastic constants of amphibole(hornblende) from Alexandrov et al. (1974).

and olivine, and the resultant seismic anisotropy are discussed.

\section{STUDIES ON THE SLIP SYSTEM AND CPOs OF OLIVINE}

Early experiments on the deformation of single crystal olivine at high pressure were performed by Rayleigh (Raleigh, 1965, 1968) under uniaxial compression and identified active slip systems of olivine by observing detailed microstructures such as kink bands, slip bands, and deformation lamellae. Slip system is defined by a slip plane and a slip direction (i.e., (010)[100] slip system refers to a slip occurring at the (010) plane and along the [100] direction). At low temperatures (less than $1,000^{\circ} \mathrm{C}$ ), the slip systems of olivine were $\{110\}[001],(100)[001]$, and (100) [010], while at the 


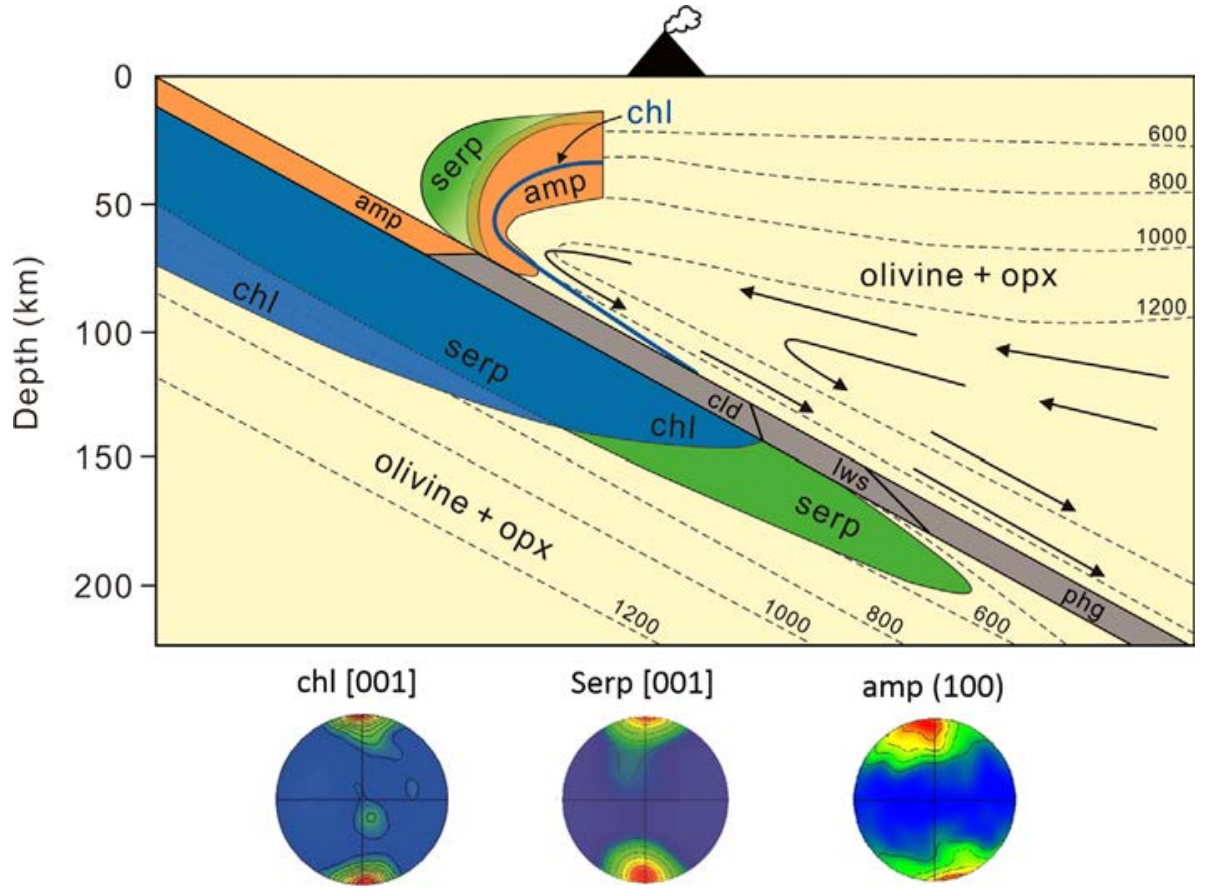

Fig. 3. Stability field of hydrous minerals in subduction zone. Stippled lines are isotherms by thermal model (Furukawa, 1993) and bold arrows indicate flow lines in the mantle wedge. Blue line indicates the stability boundary of chlorite in peridotite. Example of strong CPO of chl (Kim and Jung, 2015), serp (Jung, 2011), and amp (Ko and Jung, 2015) is shown, which is important for the interpretation of anomalously strong seismic anisotropy in subduction zones. chl: chlorite, amp: amphibole (hornblende), serp: serpentine (antigorite), opx: orthopyroxene, cld: chloritoid, Iws: lawsonite, and phg: phengite. Modified after Schmidt and Poli (1998).
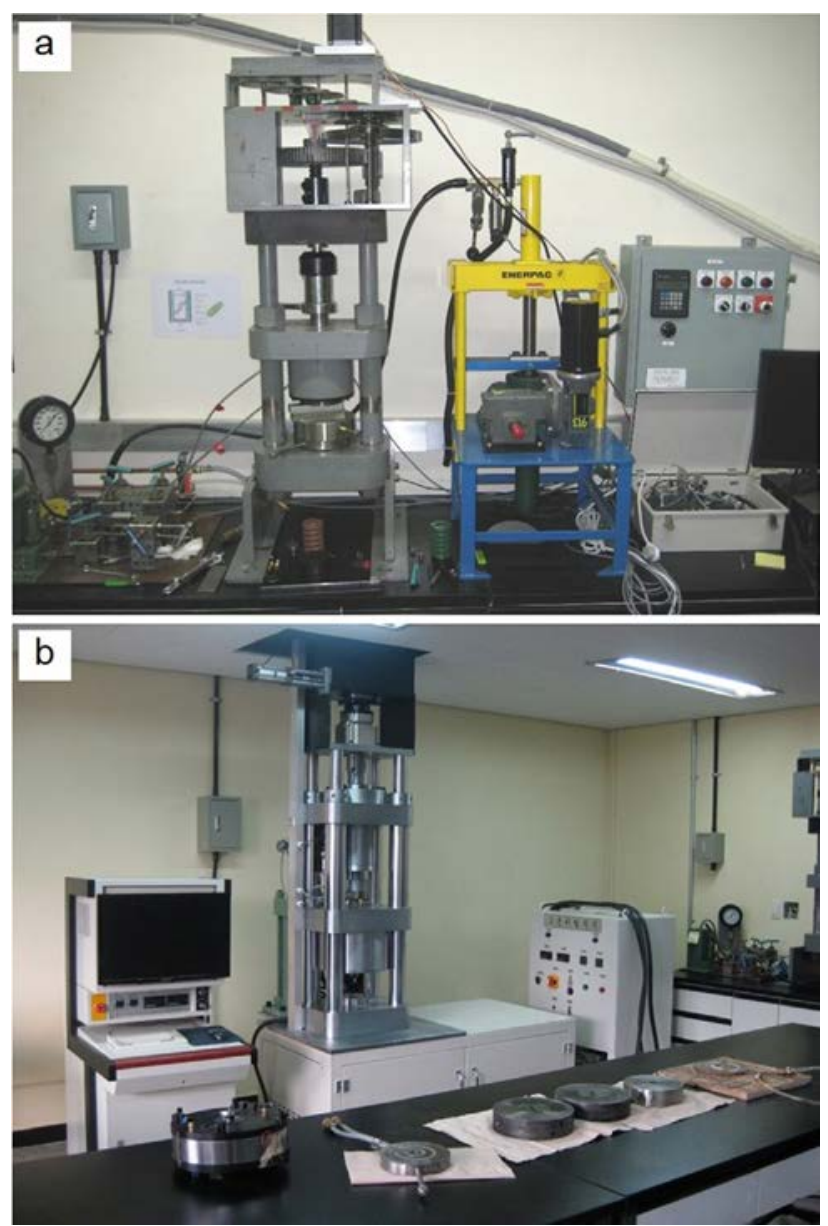

Fig. 4. Equipment used for high-temperature, high-pressure deformation experiments on minerals and rocks. (a) Griggs apparatus (2 $\mathrm{GPa}$ ), and (b) modified Griggs apparatus (5 GPa) at the Tectonophysics Laboratory, Seoul National University, South Korea. high temperature of $1,000{ }^{\circ} \mathrm{C}$, the slip system was $\{0 \mathrm{kl}\}[100]$, which is the pencil glide in [100] direction (Raleigh, 1968). Later experiments at higher pressure (up to $\mathrm{P}=3 \mathrm{GPa}$ ) and temperature (up to $1,400^{\circ} \mathrm{C}$ ) conditions (Carter and Avé Lallemant, 1970) identified the slip system of olivine as (010)[100] at temperatures in excess of $1,100^{\circ} \mathrm{C}$.

The first experimental study to determine the $\mathrm{CPO}$ of olivine aggregates was conducted in the uniaxial compression mode using a Griggs apparatus (Fig. 4a) under dry conditions (Avé Lallemant and Carter, 1970). Olivine [010] axes were found to be aligned subparallel to the maximum principal stress (strain axis) orientation. Both [100] and [001] axes were aligned in a girdle subnormal to the maximum principal stress (strain axis) orientation. In 1995, the first simple shear deformation experiment of olivine aggregates at the pressure of $300 \mathrm{MPa}$ and temperatures of $1,200-1,300^{\circ} \mathrm{C}$ was conducted using a gas-medium Paterson apparatus under dry conditions (Zhang and Karato, 1995) and more experimental data were published later (Zhang et al., 2000). These simple shear experiments showed that olivine [010] axes were aligned subnormal to the shear plane and [100] axes were aligned subparallel to the shear direction under dry conditions.

\subsection{Effect of Water and Stress on the CPOs of Olivine}

\subsubsection{Experimental study}

Water has been known to affect the CPO of olivine since the pioneering experimental study (Jung and Karato, 2001). To understand the effect of water and stress on the $\mathrm{CPO}$ of olivine, deformation experiments were conducted on olivine aggregates 


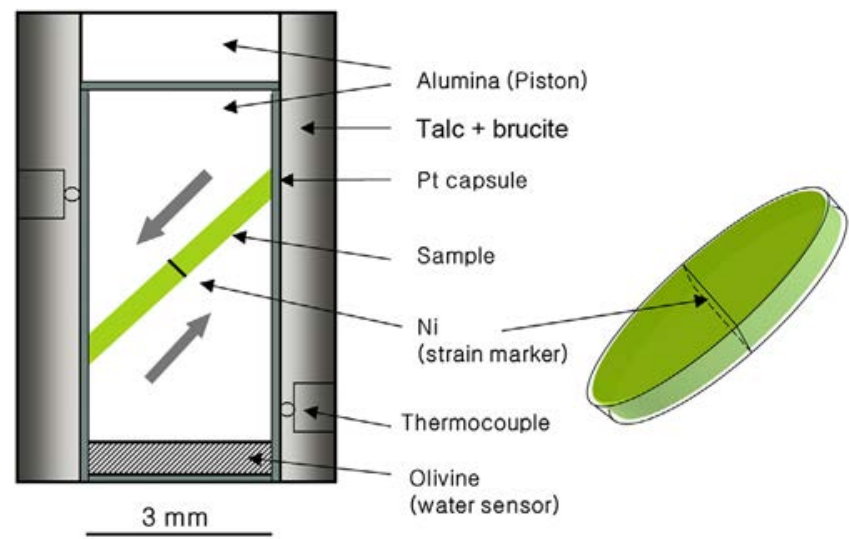

Fig. 5. Central portion of sample assembly for a shear deformation experiment at high pressure and temperature using a Griggs apparatus.

in simple shear (Fig. 5), using a Griggs apparatus (Fig. 4a) at high pressure $(0.3-2.1 \mathrm{GPa})$ and temperature $\left(1,190-1,300^{\circ} \mathrm{C}\right)$, discovering olivine Type-B and-CCPOs (Fig. 6a) and defining olivine Type-A, $-\mathrm{B},-\mathrm{C}$, and -D CPOs (Jung and Karato, 2001). The starting materials were San Carlos olivine aggregates and single crystal olivine that contained $10 \% \mathrm{Fe}$, as a representative sample of the upper mantle. The sample was hot-pressed at $300 \mathrm{MPa}$ and $1,200^{\circ} \mathrm{C}$. Experiments were conducted under both dry and wet conditions. In wet conditions, water was added to the sample by the dehydration of the mixture of talc and brucite at high temperature. Sample assembly for shear deformation experiment is shown in Figure 5. The sample was deformed at constant strain rates $\left(9.5 \times 10^{-4}-\right.$ $5.6 \times 10^{-6} \mathrm{~s}^{-1}$ ) with a shear strain of 0.6-6.3 (Jung and Karato, 2001; Katayama et al., 2004; Jung et al., 2006). Dry conditions were defined as a water content of less than $200 \mathrm{ppm} \mathrm{H} / \mathrm{Si}$ in single crystal olivine without any cracks, inclusions, or grain boundaries in the sample.

The representative CPOs of olivine produced in a simple shear at high pressures under both dry and wet conditions are summarized in Figure $6 \mathrm{a}$ and a fabric diagram of olivine is shown in Figure 6b. Several types of olivine CPOs were found: Type-A CPO of olivine was formed under low-stress and dry conditions; water content in the single crystal olivine was less than 200 ppm H/Si (Jung and Karato, 2001). The Type-A CPO of olivine is characterized by olivine [010] axes aligned subnormal to the shear plane and [100] axes aligned subparallel to the shear direction, having a dominant slip system of (010)[100]. Type-B $\mathrm{CPO}$ of olivine was found under high-stress and varied water content $\left(200 \leq \mathrm{C}_{\mathrm{OH}} \leq 1200 \mathrm{ppm} \mathrm{H} / \mathrm{Si}\right)$ conditions and characterized as [010] axes aligned subnormal to the shear plane and [001] axes aligned subparallel to the shear direction, having a dominant slip system of (010)[001] (Jung and Karato, 2001). Type-C CPO of olivine was observed under low-stress and water-rich conditions with a water content of $\mathrm{C}_{\mathrm{OH}} \geq 700 \mathrm{ppm} \mathrm{H/Si}$ and characterized

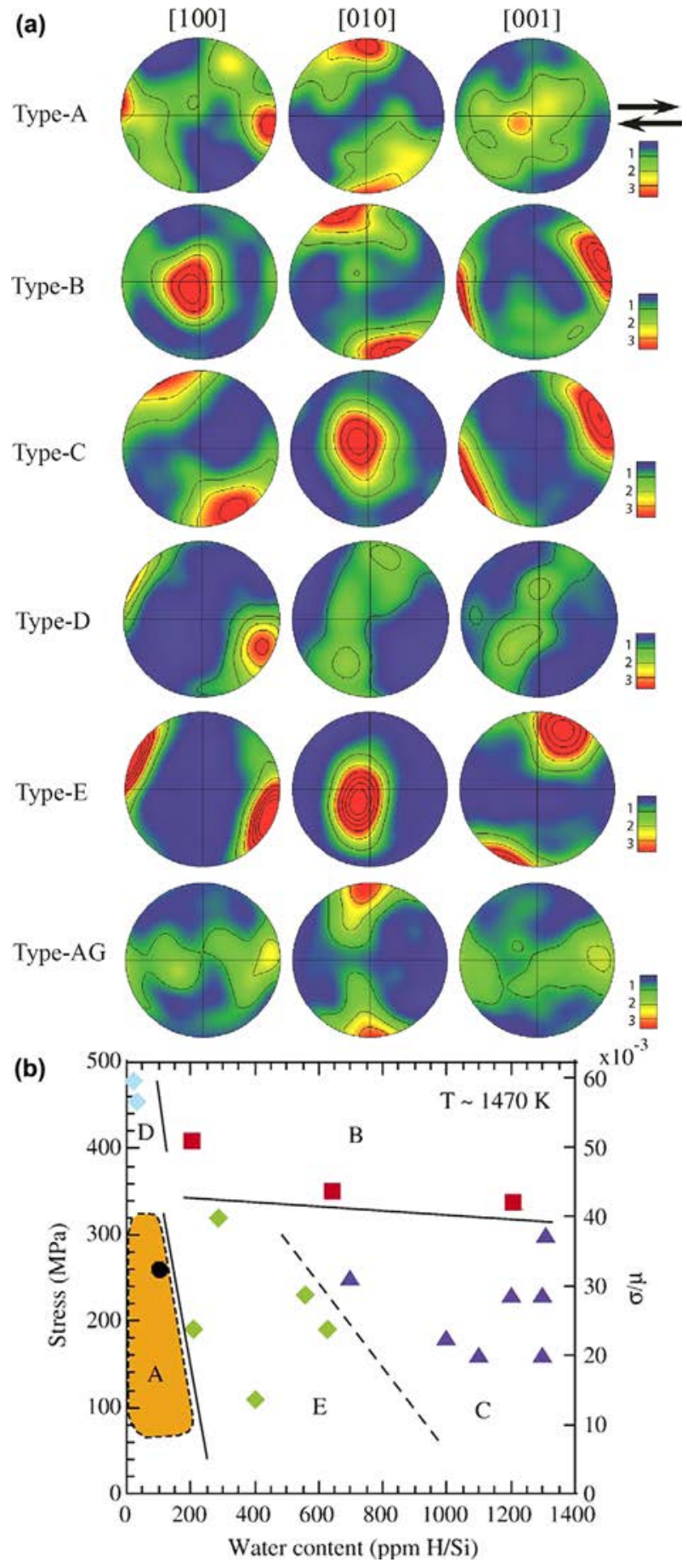

Fig. 6. (a) Typical CPOs of olivine showing Type- $A,-B,-C,-D,-E$, and -AG (modified from Jung et al., 2006). Type-A (MIT23), Type-B (JK21), Type-C (JK11), Type-D (SVF-49: Jung et al., 2009a), Type-E (GA25), and Type-AG (Jung et al., 2014b). Pole figures are presented in the lower hemisphere using an equal area projection. The sense of shear is presented by arrows. The north (south) poles correspond to the shear plane normal. Crystallographic orientations of 200-650 grains of each sample were measured manually by the EBSD technique. A half-width of $30^{\circ}$ was used to draw the pole figure. The color coding refers to the density of data points (contours in the pole figures correspond to the multiples of uniform distribution). (b) $A$ fabric diagram of olivine at $\mathrm{P}=0.3-2.1 \mathrm{GPa}$ and $\mathrm{T} \sim 1200^{\circ} \mathrm{C}$ showing the dominant fabrics as a function of water content $\left(\mathrm{C}_{\mathrm{OH}}\right)$ and stress (after Jung et al., 2006). $\sigma$ : differential stress, $\mu$ : shear modulus. 
as [100] axes aligned subnormal to the shear plane and [001] axes aligned subparallel to the shear direction, having a dominant slip system of (100)[001] (Jung and Karato, 2001). Type-D CPO of olivine was formed under high-stress and dry conditions and characterized as [100] axes aligned subparallel to the shear direction and both [010] and [001] axes aligned as a girdle subnormal to shear direction, having a dominant slip system of $\{0 \mathrm{kl}\}[100]$ (Bystricky et al., 2000; Zhang et al., 2000). Finally, Type-E CPO of olivine was found under low-stress and moderate water content $\left(200 \leq \mathrm{C}_{\mathrm{OH}}<700 \mathrm{ppm} \mathrm{H} / \mathrm{Si}\right)$ conditions and characterized as [001] axes aligned subnormal to the shear plane and [100] axes aligned subparallel to the shear direction, having a dominant slip system of (001)[100] (Katayama et al., 2004; Jung et al., 2006).

Based on the study of natural rocks, one more CPO of olivine, Type-AG (Mainprice, 2007; Michibayashi et al., 2016), sometimes called as axial [010] pattern (Tommasi and Vauchez, 2015), was reported. It is characterized by [010] axes strongly aligned subnormal to the foliation and both [100] and [001] axes aligned subparallel to the foliation (Fig. 6a). The Type-AG CPO of olivine was also called type A + B CPO ( type $\mathrm{A}+$ type $\mathrm{B}$ CPO) because it can be formed under a mixed condition (deformed in dry condition and later in wet condition, vice versa) (Jung et al., 2014b).

\subsubsection{Observation of water-induced CPOs of olivine in natural rocks}

Early studies of olivine CPOs in natural rocks were conducted by Nicolas and Christensen (1987) and Ben Ismail and Mainprice (1998). Since water-induced CPOs of olivine were discovered in experimental studies (Jung and Karato, 2001; Katayama et al., 2004; Jung et al., 2006), there has been active research on the petrofabrics of olivine in natural rocks (Table 3). Mizukami et al. (2004) reported on the water-induced Type-B CPO of olivine in the peridotites in Higashiakaishiyama, southwest Japan. Frese et al. (2003) found Type-C CPOs of olivine in prograde garnet peridotites in Cima di Gagnone, in the Central Alps, and reported that the fabrics formed at high water activity. Skemer et al. (2006) also reported the Type-B CPO of olivine in the peridotites in Cima di Gagnone in the presence of water. Tasaka et al. (2008) reported water-induced Type-B CPO in highly depleted dunites from the Imono peridotite body within the subduction-type Sanbagawa metamorphic belt in southwest Japan. Jung (2009) found both Type-B and Type-E CPOs of olivine in serpentinized peridotites in Val Malenco, Italy. Skemer et al. (2013) reported the water-induced Type-E CPO of olivine from Josephine peridotites in southwest Oregon, in the United States. Michibayashi and Oohara (2013) reported C- and E-type CPOs of olivine in a hydrated ductile shear zone from the Fizh massif, Oman ophiolite.

Table 3. Water-induced CPOs of olivine found in natural rocks

\begin{tabular}{|c|c|c|c|}
\hline Fabric type & Rock type & Location & Reference \\
\hline \multirow[t]{9}{*}{ B-type } & Dunite & Higashiakaishiyama, SW Japan & Mizukami et al. (2004) \\
\hline & Garnet peridotite & Cima di Gagnone, Central Alps & Skemer et al. (2006) \\
\hline & Depeleted dunite & Snabagawa metamorphic belt, Japan & Tasaka et al. (2008) \\
\hline & Serpentinized peridotite & Val Malenco, Italy & Jung (2009) \\
\hline & Mylonitic peridotite & Bergen arc, Western Norway & Jung et al. (2014b) \\
\hline & Spinel peridotite & Shanwang, Eastern China & Park \& Jung (2015) \\
\hline & Chlorite peridotite & Amklovdalen, WGR, Western Norway & Kim \& Jung (2015) \\
\hline & Mylonitic peridotite & Navajo volcanic fiend, Colorado Plateau, USA & Behr \& Smith (2016) \\
\hline & Spinel lherzolitie & El Aprisco, Calatrava volcanic field, Spain & Puelles et al. (2016) \\
\hline \multirow[t]{5}{*}{ C-type } & Garnet peridotite & Cima di Gagnone, Central Alps & Frese et al. (2003) \\
\hline & Garnet peridotite & Otroy Island, WGR, Western Norway & Katayama et al. (2005) \\
\hline & Garnet peridotite & North Quidam UHP belt, NW China & Jung et al. (2013) \\
\hline & Spinel peridotite & Adam's Diggings, Rio Grande rift, USA & Park et al. (2014) \\
\hline & Spinel lherzolitie & El Aprisco, Calatrava volcanic field, Spain & Puelles et al. (2016) \\
\hline \multirow[t]{8}{*}{ E-type } & Serpentinized peridotite & Val Malenco, Italy & Jung (2009) \\
\hline & Harzburgite & Josephine peridotite, SW Oregon, USA & Skemer et al. (2013) \\
\hline & Dunite & Fizh massif, Oman ophiolite & Michibayashi \& Oohara (2013) \\
\hline & Mylonitic peridotite & Bergen arc, Western Norway & Jung et al. (2014b) \\
\hline & Spinel peridotite & Shanwang, Eastern China & Park \& Jung (2015) \\
\hline & Chlorite peridotite & Amklovdalen, WGR, Western Norway & Kim \& Jung (2015) \\
\hline & Spinel peridotite & Yugu, South Korea & Park \& Jung (2017) \\
\hline & Mylonitic peridotite & Ronda massif, Southern Spain & Précigout et al. (2017) \\
\hline
\end{tabular}


Jung et al. (2013) found water-induced strong Type-C CPOs in ultra-high-pressure (UHP) garnet peridotites from the North Qaidam UHP collision belt in northwest China. In that study the olivine contained water up to $\mathrm{C}_{\mathrm{OH}}=1,130 \pm 50 \mathrm{ppm} \mathrm{H} / \mathrm{Si}$, the highest water content in olivine with the Type-C CPO in natural rock.

Park et al. (2014) reported Type-C CPOs of olivine in the mantle xenoliths from the Adam's Diggings at a rift shoulder in the Rio Grande rift in the US, where spinel peridotites showed evidence of rock deformation under wet conditions. Jung et al. (2014b) found Type-B and -E CPOs of olivine in the peridotite mylonites under a wet environment in the Bergen arc in western Norway. Park and Jung (2015) reported Type-B and -E CPOs of olivine in the spinel peridotites from mantle xenoliths in Shanwang, eastern China. Kim and Jung (2015) studied chlorite peridotites from Amklovdalen in the western gneiss region in western Norway and reported both Type-B and Type-E CPOs of olivine. Behr and Smith (2016) reported Type-B CPOs of olivine in the mantle xenoliths from a mantle wedge setting in the Navajo volcanic field in the Four Corners region of the Colorado Plateau, the US, confirming that this fabric does form in natural subduction zones. Czertowicz et al. (2016) reported dislocation glide on Etype slip system in the coarse pre-mylonitised grains of olivine under hydrous condition in Anita shear zone in New Zealand, probably within hydrated sub-arc mantle lithosphere. Puelles et al. (2016) reported both Type-B and -C CPOs of olivine in the mantle xenoliths in El Aprisco in the Calatrava volcanic field in central Spain. Recent study on microstructures of Pinatubo peridotite xenoliths Yamamoto et al. (2017) found some dislocations with the (001)[100] slip system in olivine which could have been formed by the deformation under moderate water content and low-temperature conditions. Park and Jung (2017) recently reported Type-E CPOs of olivine in the ultramylonites (Figs. 2e and 7) from the Yugu peridotite body in Yugu, South Korea. Precigout et al. (2017) also found Type-E CPOs of olivine in the mylonitic peridotites in the Ronda massif, Southern Spain.

\subsection{Effect of Temperature and Pressure on the CPOs of Olivine}

\subsubsection{Effect of temperature on the CPOs of olivine}

Katayama and Karato (2006) investigated the effect of temperature on the $\mathrm{CPO}$ of olivine at $\mathrm{P}=2 \mathrm{GPa}$ and $\mathrm{T}=1,000-1,100^{\circ} \mathrm{C}$. Samples were deformed at the constant strain rates of $3.8 \times 10^{-4}$ $3.2 \times 10^{-5} \mathrm{~s}^{-1}$ under water-saturated conditions using the Griggs apparatus. The Type-B CPO of olivine occurred at higher stresses than the Type-C CPO. In addition, the stress magnitude at which the Type-B to -C CPO transition occurs decreased significantly with decreasing temperature.

\subsubsection{Effect of pressure on the CPOs of olivine}

Couvy et al. (2004) studied the effect of pressure on the CPO of olivine, performing relaxation experiments on forsterite $\left(\mathrm{Mg}_{2} \mathrm{SiO}_{4}\right)$ aggregates using a multi-anvil apparatus at $\mathrm{P}=11 \mathrm{GPa}$ and $\mathrm{T}=$ $1,400^{\circ} \mathrm{C}$. In that study, shear strain was limited to $\gamma=0.2$ because of the conditions of the experimental facility, but a weak Type-C $\mathrm{CPO}$ of olivine was observed, suggesting that high pressure makes Type-C fabric. However, this result is associated with the following uncertainties: (1) the analysis of water content of olivine

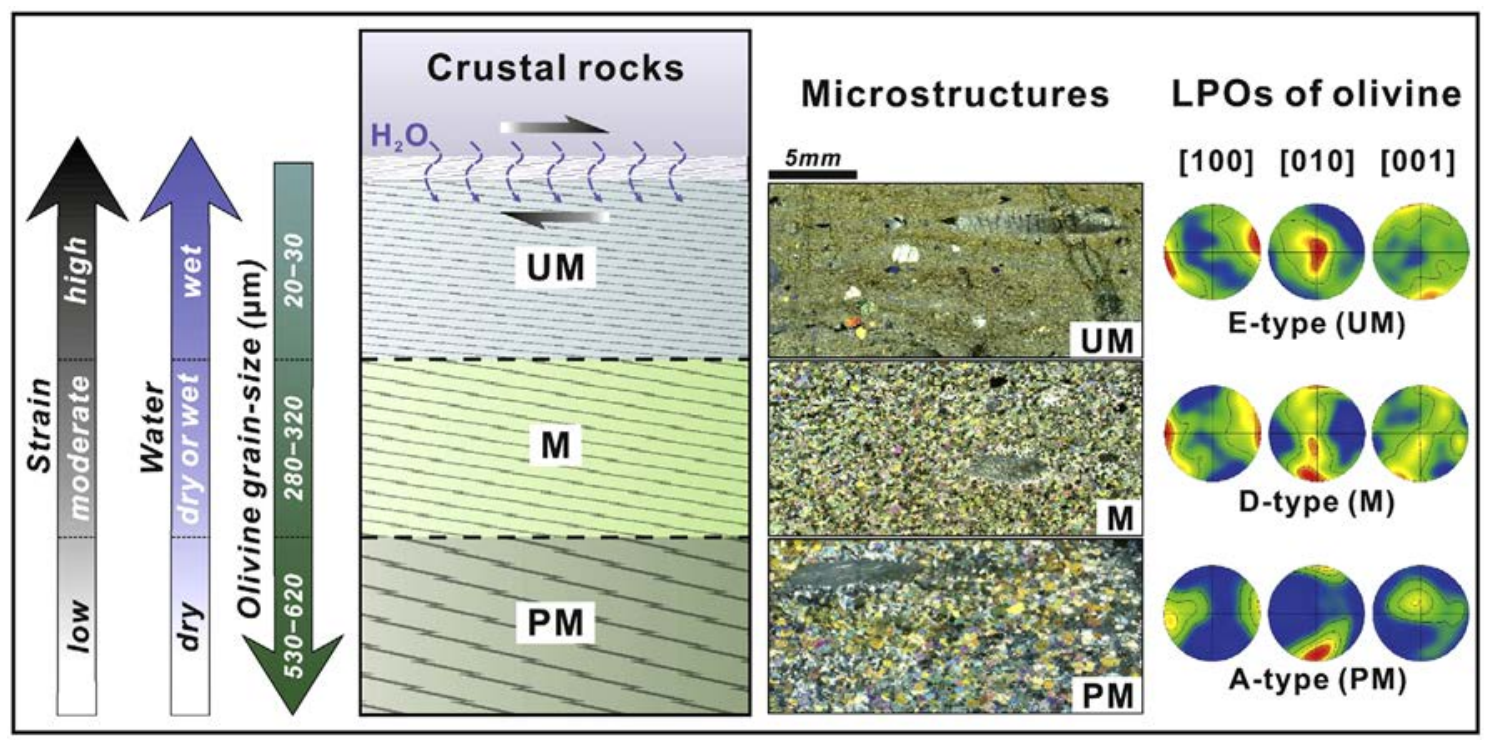

Fig. 7. Microstructural evolution and CPO evolution of olivine in the Yugu peridotites in Yugu, South Korea (Park and Jung, 2017). From protomylonite (PM) via mylonite (M) to ultra-mylonite (UM), both shear strain and water activity are increased whereas recrystallized grain-size of olivine is decreased. Crystal preferred orientations (CPOs) of olivine are changed with the textural types of peridotites, from A-type (PM) via D-type (M) to E-type (UM). 
after the experiments using Fourier Transformation Infrared (FTIR) spectroscopy revealed that the samples contained a large amount of water (1,500-2,500 ppm H/Si). Deformation of olivine in wet conditions $\left(\mathrm{C}_{\mathrm{OH}} \geq 700 \mathrm{ppm} \mathrm{H} / \mathrm{Si}\right)$ can produce Type- $\mathrm{C}$ CPO of olivine (Jung and Karato, 2001); (2) stress was varied during the experiment from 100 to $1,500 \mathrm{MPa}$ because of the stress-relaxation experiment. High stress favors [001] slip in olivine (Carter and Avé Lallemant, 1970) and can induce changes in olivine fabric (Jung et al., 2006; Katayama and Karato, 2006); (3) the sample of forsterite used contained no Fe in olivine, whereas olivine in nature is Fe-bearing in the upper mantle $(\sim 10 \%)$; and (4) the shear strain was so small $(\gamma=0.2)$ that it is not certain that the CPO represents the real fabric of the Earth where shear strain is considered large.

More experimental studies of olivine aggregates at high pressure were performed by exercising great care on the water content, stress, and shear strain and pressure was found to induce changes in the olivine CPO from Type-A to Type-B above $3 \mathrm{GPa}$ (Jung et al., 2009b). Deformation experiments of natural olivine aggregates
$\left(\left(\mathrm{Mg}_{0.9} \mathrm{Fe}_{0.1}\right)_{2} \mathrm{SiO}_{4}\right)$ were conducted using a modified Griggs apparatus at $\mathrm{P}=2.5-3.6 \mathrm{GPa}$ and $\mathrm{T}=1,300^{\circ} \mathrm{C}$ under dry conditions $\left(\mathrm{C}_{\mathrm{OH}} \leq 90 \mathrm{ppm} \mathrm{H} / \mathrm{Si}\right)$ with a large shear strain $(\gamma=3-6)$. Samples were deformed at constant strain rates $\left(2 \times 10^{-4}-6 \times 10^{-5} \mathrm{~s}^{-1}\right)$ and the CPO of olivine was measured using the SEM/EBSD (scanning electron microscope/electron backscattered diffraction) technique at the Seoul National University in South Korea. Olivine Type-B $\mathrm{CPO}$ was developed at the pressures of $3.1 \mathrm{GPa}$ and $3.6 \mathrm{GPa}$ and the temperature of $1,300^{\circ} \mathrm{C}$ whereas Type-A CPO was formed at the low pressure of $2.5 \mathrm{GPa}$ with other conditions similar to the higher-pressure experiments (Fig. 8) (Jung et al., 2009b). The pressure-induced Type-B CPO of olivine occurred at the pressure greater than $3 \mathrm{GPa}$. A subsequent study on the deformation of olivine aggregates using the D-Dia (deformation-dia), a multianvil high-pressure apparatus, confirmed that similar Type- $\mathrm{B}$ CPO of olivine was formed at $5 \mathrm{GPa}$ (Ohuchi et al., 2011).

Recently, more experiments were performed on the deformation of olivine aggregates at high pressure under wet and dry conditions (Ohuchi and Irifune, 2013, 2014; Ohuchi et al., 2015). To

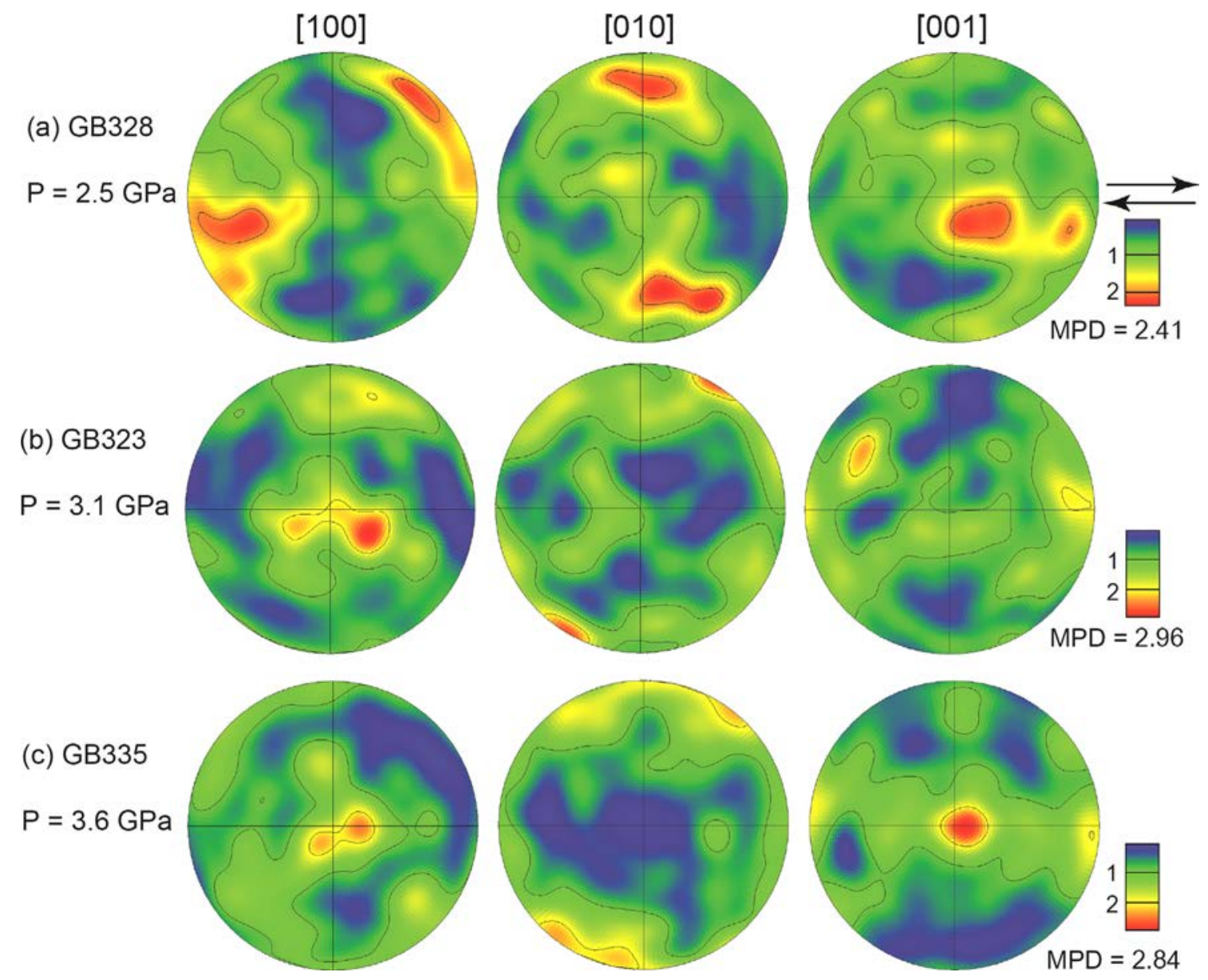

Fig. 8. Pole figures of olivine showing the effect of pressure on the CPO of olivine (after Jung et al., 2009b). Arrows show the shear sense, and north-south poles correspond to the shear plane normal. Contours correspond to multiples of a uniform distribution of data points. In all three specimens represented here, the water content was undetectable. (a) $\mathrm{T}=1300^{\circ} \mathrm{C}, \gamma=3$, differential stress $=120 \mathrm{MPa}$. (b) $\mathrm{T}=1300^{\circ} \mathrm{C}$, $\gamma=3$, differential stress $=150 \mathrm{MPa}$. (c) $\mathrm{T}=1300^{\circ} \mathrm{C}, \gamma=6$, differential stress $=390 \mathrm{MPa}$. A half-width of $20^{\circ}$ was used to draw the pole figures. $\mathrm{MPD}=$ maximum pole figure density. 
compare the olivine CPOs in those studies, one needs to pay attention to the measurement of olivine water content. The water content of olivine (Jung and Karato, 2001; Jung et al., 2006) was originally measured inside single crystal olivine without any cracks, inclusions, or grain boundaries. Recently, Soustelle and Manthilake (2017) deformed olivine-orthopyroxene aggregates under simple shear at high pressures using the multi-anvil press with shear strains of $\gamma=0.5-1.3$. They found that the Type-B $\mathrm{CPO}$ of olivine developed at high pressures of 3, 5, and $8 \mathrm{GPa}$ for olivine plus orthopyroxene content of $12.5 \%$ and $25 \%$ at the temperatures of $1,300,1,400$, and $1,500^{\circ} \mathrm{C}$, respectively.

\subsubsection{Natural example of pressure-induced CPOs of olivine}

Deformation fabrics of olivine from diamond-bearing garnet peridotites in Finsch, South Africa were studied (Lee and Jung, 2015). They found strong Type-B CPOs of olivine in the samples originated from a depth of $120 \mathrm{~km}\left(\mathrm{P}=4 \mathrm{GPa}, \mathrm{T}=1,000{ }^{\circ} \mathrm{C}\right)$ based on the analysis of the chemical composition of minerals (thermobarometry data from the electron microprobe analysis) and the existence of diamonds in garnet peridotites. Measurements of the water content of both olivine and orthopyroxene using FTIR spectroscopy revealed that both olivine and orthopyroxenes are dry, indicating that strong Type-B CPOs of olivine were formed under dry and high-pressure conditions. These observations indicate that the strong Type-B CPOs in garnet peridotites of Finsch, South Africa is the first natural example of pressure-induced fabrics of olivine.

\subsection{Effect of Large Shear Strain and Deformation History on the CPOs of Olivine}

\subsubsection{Effect of large shear strain on the CPOs of olivine}

The first shear deformation experiment of olivine aggregates under dry conditions using the torsion apparatus for a large shear strain (up to $\gamma=5$ ) was conducted by Bystricky et al. (2000) at the pressure of $300 \mathrm{MPa}$ and $1,200^{\circ} \mathrm{C}$. They reported a Type-D $\mathrm{CPO}$ of olivine at shear strains of $\gamma=2,4$, and 5. Later, Hansen et al. (2012) deformed olivine aggregates $\left(\mathrm{Fo}_{50}\right)$ for a large shear strain (up to $g \sim 10$ ) using a torsion apparatus under dry conditions at $\mathrm{P}=250 \mathrm{MPa}$ and $1200{ }^{\circ} \mathrm{C}$. The Type-D CPO of olivine was observed at a shear strain of $\gamma \sim 3.5$, but the Type-A CPO was observed at a shear strain of $\gamma \sim 10$. To examine the systematics of the evolution of olivine crystallographic fabrics at high strain, Hansen et al. (2014) conducted more torsion experiments on olivine aggregates $\left(\mathrm{Fo}_{50}\right)$ under dry conditions at the pressures of 250 and $300 \mathrm{MPa}$ and at $1200^{\circ} \mathrm{C}$ with shear strains of up to $\gamma \sim 19$. A steady-state fabric was not reached until the shear strain was greater than 10 . The authors showed that Type-D CPOs of olivine developed with increasing strains up to $\gamma=9$ and $\gamma=14$, and showed Type-A CPOs at shear strains of $\gamma=7,10,11$, and 19. These results indicate that more study is probably needed to understand the development of CPOs of olivine with large shear strain.

\subsubsection{Effect of deformation history on the CPOs of olivine}

Recently, the effect of deformation history on the $\mathrm{CPO}$ of olivine was studied by Boneh and Skemer (2014) using natural samples of Åheim dunite that had a pre-existing CPO of olivine. Deformation experiments were conducted using the Griggs apparatus at $1 \mathrm{GPa}$ and $1,200^{\circ} \mathrm{C}$ with uniaxial strain (0.7). Samples were deformed in three orientations, in which the shortening was imposed perpendicular, oblique, and parallel to the pre-existing foliation. The evolution of the $\mathrm{CPO}$ of olivine was distinct for three initial orientations and none of the $\mathrm{CPO}$ sas observed to reach steady state.

Numerical modeling studies on the olivine $\mathrm{CPO}$ development were performed previously, producing a strong $\mathrm{CPO}$ of olivine (Wenk and Tomé, 1999; Tommasi et al., 2000; Kaminski and Ribe, 2001, 2002; Kaminski et al., 2004; Castelnau et al., 2008; Castelnau et al., 2009; Castelnau et al., 2010). Recent numerical studies on the development of olivine CPO using the dynamic recrystallization-induced LPO (D-Rex) and the viscoplastic self-consistent (VPSC) models (Boneh et al., 2015) identified similar trends suggesting that a large strain is required to reach a steady state $\mathrm{CPO}$. In many cases, models initiated with a preexisting $\mathrm{CPO}$ require greater strain (about 3-5 times) to reach steady state CPO than models initiated with a uniform CPO. Signorelli and Tommasi (2015) modified a viscoplastic selfconsistent code to simulate the effects of subgrain rotation recrystallization on the $\mathrm{CPO}$ of olivine. They found that the easy slip system rotates fast towards parallelism with imposed shear and that steady-state $\mathrm{CPO}$ (orientation and intensity) is reached at shear strains of $\gamma>5$.

\subsection{CPOs of Olivine in Natural Shear Zones}

CPOs of olivine in natural shear zones were studied in Josephine Peridotite in southeastern Oregon, US (Warren et al., 2008; Skemer et al., 2010; Hansen and Warren, 2015), in the Red Hills, New Zealand (Webber et al., 2008), in the Hilti massif, Semail ophiolite, Oman (Linckens et al., 2011), in an extensional shear zone in the mantle, Lanzo massif, Italy (Kaczmarek and Tommasi, 2011), in an oblique-slip low-angle shear zone in the Beni Bousera peridotite (Rif Belt, Morocco) (Frets et al., 2014), in the mylonitic peridotites in the Ronda massif, Southern Spain (Precigout et al., 2017), and in Yugu peridotites in South Korea (Fig. 7) (Park and Jung, 2017). These studies suggested that the re-orientation 
of olivine in rocks with pre-existing textures requires large strains. For example, a shear strain of $\gamma>4$ was needed to re-orient the CPOs of olivine with respect to the shear zone kinematics (Hansen and Warren, 2015).

\subsection{Other Possibilities for the Formation of the CPOs of Olivine}

Experimental study at the pressure of $300 \mathrm{MPa}$ and temperature of $1200^{\circ} \mathrm{C}$ (Holtzman et al., 2003) reported, in the presence of melt, a Type-B like $\mathrm{CPO}$ of olivine which is characterized as a strong concentration of [010] axes aligned subnormal to the shear plane and a weak girdle of both [100] and [001] axes aligned subparallel to the shear plane. However, this type of melt-induced $\mathrm{CPO}$ of olivine has been rarely reported in natural rocks. There is also a report of the development of $\mathrm{CPO}$ of iron-free olivine (forsterite) which was experimentally produced during diffusion creep at the temperature of $1,200-1,350^{\circ} \mathrm{C}$ (Miyazaki et al., 2013). Fabric analysis of olivine in spinel peridotite xenoliths of Jeju Island in South Korea (Yang et al., 2010) showed a weak activation of $\{0 \mathrm{kl}\}$ [100] slip system in the porphyrocalstic and mylonitic peridotites. The results of the trace element analysis in that study revealed that the smaller the grain size and weaker the fabric, the more enriched in LREE and HFSE are the peridotites, indicating a strong relationship between metasomatic agents and mantle shear zones.

A weak Type-C CPO of olivine was reported in Xugo UHP garnet peridotites from the southern Sulu UHP terrane in China (Wang et al., 2013b). The Type-C CPO of olivine was generated by a dominant dislocation-accommodated grain boundary sliding (DisGBS) with a minor contribution from the diffusion creep at elevated pressure. Nagaya et al. (2014) reported that the Type-B $\mathrm{CPO}$ of olivine can form as a result of the static topotactic growth of olivine after the high-temperature breakdown of foliated serpentinite. Wang et al. (2013a) reported Type-B CPO of olivine in dunite from Raudkleivane, Amklovdalen and Type-C CPO of olivine in garnet harzburgite from Ugelvik, Otroy in Norway. Based on low water content in olivine, they interpreted that those $\mathrm{CPOs}$ were produced by high stress or high pressure. However, there is a high possibility that water in olivine was lost during exhumation process because of high diffusivity of hydrogen in olivine (Mackwell and Kohlstedt, 1990).

The Type-B CPO of olivine was also reported in peridotites from the Ronda massif in Spain (Precigout and Hirth, 2014). The Type-B CPO was suggested to be resulted from the enhancement of the grain boundary sliding (GBS) with decreasing grain size. The effect of finite strain geometry on $\mathrm{CPO}$ of olivine was investigated using naturally deformed mantle rocks (Chatzaras et al., 2016). They showed that finite strain geometry controls the development of axial-type olivine CPO; axial-[010] and axial-
[100] CPOs form in relation to oblate and prolate fabric ellipsoids, respectively. Cao et al. (2017) reported CPOs of olivine similar to Types $C$ and $B$ in Songshugou peridotites and suggested that those CPOs were formed by a diffusion-accommodated grain boundary sliding (DifGBS) at high temperatures.

\subsection{Scaling to the Nature}

Because some of the conditions in experimental studies (e.g., the strain-rates) are different from those in the Earth, we need to understand the scaling law for fabric transitions if experimental results were to be applied to the Earth. This issue was already discussed in previous study (Jung et al., 2006) and is summarized below. Any fabric transition occurs when the rates of two processes (e.g., strain-rates of two slip systems) become similar. Therefore a generic equation to define a fabric boundary is

$$
\mathrm{A}_{1}\left(\mathrm{~T}, \mathrm{P}, \mathrm{C}_{\mathrm{OH}}, \sigma\right)=\mathrm{A}_{2}\left(\mathrm{~T}, \mathrm{P}, \mathrm{C}_{\mathrm{OH}}, \sigma\right) \text {, }
$$

where $A_{1}$ and $A_{2}$ are the rates of processes responsible for a fabric development (e.g., strain-rate), $\mathrm{T}$ is the temperature, $\mathrm{P}$ is the pressure, $\mathrm{C}_{\mathrm{OH}}$ is the water content, and $\sigma$ is the stress. Therefore, the transition conditions between two types of fabric are given by a hyper-surface defined as,

$$
f\left(\mathrm{~T}, \mathrm{P}, \mathrm{C}_{\mathrm{OH}}, \sigma\right)=0 \text {. }
$$

In most cases, the rates of these processes can be given by a set of non-dimensional variables as

$$
A_{1}^{\prime}\left(\frac{T}{T_{m}(P)}, C_{O H}, \frac{\sigma}{\mu(P, T)}\right)=A_{2}^{\prime}\left(\frac{T}{T_{m}(P)}, C_{O H}, \frac{\sigma}{\mu(P, T)}\right)
$$

and consequently

$$
f^{\prime}\left(\frac{T}{T_{m}(P)}, C_{O H}, \frac{\sigma}{\mu(P, T)}\right)=0 .
$$

Therefore, the boundaries between different types of CPO can be given by a hyper-surface in a multi-dimensional space that does not include strain-rate explicitly. Therefore, the fabric boundaries do not explicitly depend on strain-rates so that the fabric boundaries determined by laboratory experiments can be applied to the Earth's interior where deformation occurs at much slower strain-rates. The only difference between laboratory and Earth is that because laboratory experiments are conducted at much faster strain-rates than those in Earth, laboratory studies can explore only limited range of parameter space (e.g., relatively high stress regions).

\section{CPOS OF ORTHOPYROXENE}

Orthopyroxene is the second dominant mineral in the upper 
mantle and constitutes most of the upper mantle along with olivine (Ringwood, 1970). To better understand the seismic anisotropy in the upper mantle, one needs to understand the CPO of orthopyroxene as well (Jung et al., 2010). However, experimental studies on the $\mathrm{CPO}$ of orthopyroxene are very limited. According to a review on the CPOs of orthopyroxene in natural mantle rocks (Christensen and Lundquist, 1982), the $\mathrm{CPO}$ of orthopyroxene is characterized as [100] axes aligned normal to foliation and [001] axes aligned parallel to the lineation, indicating a major slip system of (100)[001]. This type of orthopyroxene $\mathrm{CPO}$ was classified and defined as Type-AC CPO (Fig. 9) (Jung et al., 2010), which has been the most commonly observed CPO in natural rocks (Ishii and Sawaguchi, 2002; Skemer et al., 2006; Xu et al., 2006; Hidas et al., 2007; Tommasi et al., 2008; Soustelle et al., 2009; Jung et al., 2010; Puelles et al., 2012). There are three other types of orthopyroxene CPOs found in the study of mantle xenoliths in the Spitsbergen, Svalbard in the Arctic (Jung et al., 2010). Figure 9 shows the Type-AC $\mathrm{CPO}$ of orthopyroxene as well as three others (Type- $\mathrm{AB},-\mathrm{BC}$, and $-\mathrm{ABC}$ ) (Jung et al., 2010). The Type-AB CPO of orthopyroxene was defined as [100] axes aligned subnormal to the foliation and [010] axes aligned subparallel to the lineation. The Type-BC CPO of orthopyroxene was defined as [010] axes aligned subnormal to the foliation and [001] axes aligned as subparallel to the lineation. The Type-ABC CPO of orthopyroxene was defined as both [100] and [010] axes aligned as a girdle subnormal to the lineation and [001] axes aligned subparallel to the lineation. The reason for the occurrence of different $\mathrm{CPO}$ types of orthopyroxene was considered to be a modal proportion of orthopyroxene in the sample (Jung et al., 2010), but it is still not clearly understood.

Effects of $\mathrm{Al}$ and water on the $\mathrm{CPO}$ of $\mathrm{MgSiO}_{3}$ enstatite, anhydrous and hydrous aluminous enstatite had been investigated at the pressure of $1.5 \mathrm{GPa}$ and temperature of $1,100^{\circ} \mathrm{C}$ using DDia apparatus (Manthilake et al., 2013). In $\mathrm{MgSiO}_{3}$ enstatite and hydrous aluminous enstatite, dislocations showing (100)[001] slip systems (i.e., Type-AC CPO) was observed. However, EBSD analysis of anhydrous aluminous enstatite indicated operation of (010) [001] slip system which produces Type-BC CPO. There are two other experimental studies on the deformation of twophase mixtures of orthopyroxene and olivine. Sundberg and Cooper (2008) conducted deformation experiments of samples at $1.6 \mathrm{GPa}$ and $1,200^{\circ} \mathrm{C}$, using the Griggs apparatus, and reported that orthopyroxene shows Type-AC CPO (Fig. 9) for samples with an olivine:orthopyroxene ratio of (35:65\%). Recently, at
Type-AB

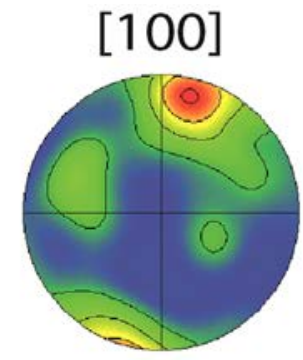

Type-AC

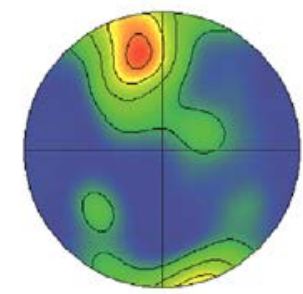

Type-BC

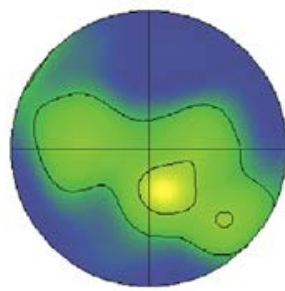

Type-ABC

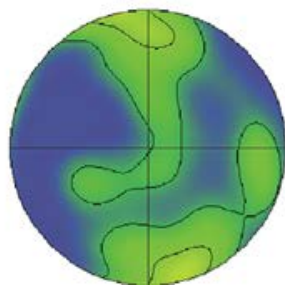

[010]
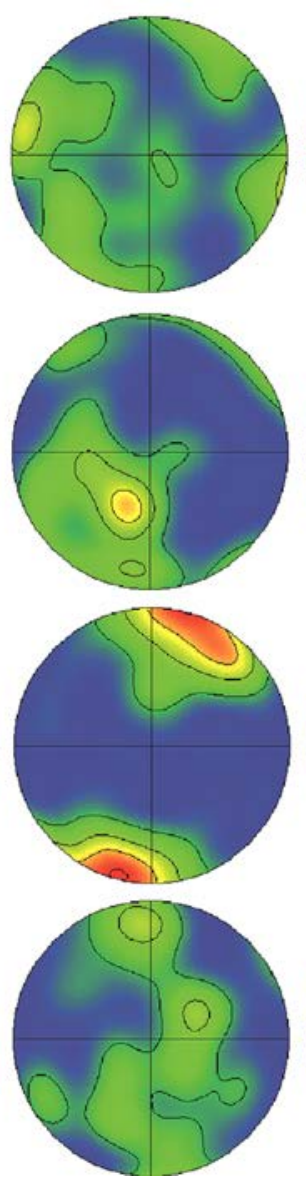
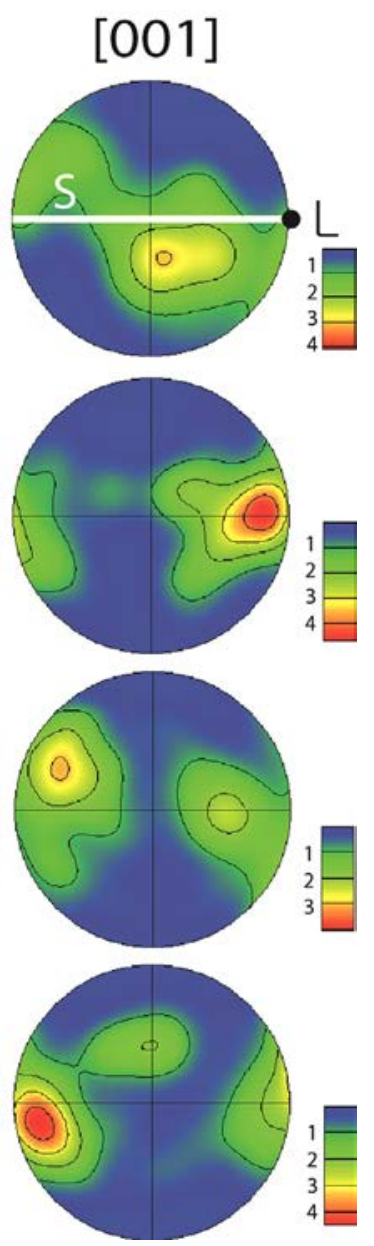

Fig. 9. Representative pole figures of orthopyroxene (opx: enstatite). Four types of CPOs of orthopyroxene are shown after Jung et al. (2010). Pole figures of the crystallographic orientation of enstatite are presented in the upper hemisphere using an equal area projection. The color coding refers to the density of data points (the numbers in the legend correspond to the multiples of uniform distribution). Type-AB: sample SVF-04, N = 172. Type-AC: sample SVF$49, \mathrm{~N}=176$. Type-BC: sample SVF-30, N $=138$. Type-ABC: sample SVF-71, N = 168. A half scatter width of $30^{\circ}$ was used. S: foliation, L: lineation. 
high pressures of 3,5 , and $8 \mathrm{GPa}$ and high temperatures of $1,300,1,400$, and $1,500^{\circ} \mathrm{C}$, respectively, Soutelle and Manthilake (2017) deformed samples (a mixture of olivine and orthopyroxene) using D-Dia at shear strains of 0.5-1.3. They found that CPOs of orthopyroxenes are ABC-type (Jung et al., 2010) for samples with olivine:orthopyroxene ratios of (50:50\%), characterized as [001] axes aligned subparallel to the shear direction and both [100] and [010] axes aligned subnormal to the shear direction.

\section{CPOS OF SERPENTINE (ANTIGORITE)}

To understand the CPO development of serpentine, deformation experiments were conducted on serpentinite under simple shear at the high pressure of $1 \mathrm{GPa}$ and temperatures of 300 and $400{ }^{\circ} \mathrm{C}$ using a Griggs apparatus (Katayama et al., 2009). The sample was serpentinite consisting mostly of antigorite. The authors found that the antigorite CPO was characterized as [001] axes aligned subnormal to the shear plane and [100] axes aligned subparallel to the shear direction. Similar CPOs of serpentine were observed in few natural samples (Bezacier et al., 2010; Brownlee et al., 2013).

On the other hand, CPOs of serpentine (antigorite) in natural rock were investigated using serpentinites from Val Malenco and Punta Bettolina in northwest Italy (Jung, 2011). The amount of serpentine in the samples varied between $40 \%$ and $93 \%$. The CPO of antigorite is characterized as [001] axes aligned subnormal to the foliation but [010] axes aligned subparallel to the lineation (Figs. 10a-c), consistent with other observations of the CPOs of antigorite in many natural rocks (Hirauchi et al., 2010; Soda and Takagi, 2010; Nishii et al., 2011; Brownlee et al., 2013; Nagaya et al., 2014; Watanabe et al., 2014). However, for reasons that are not yet understood, the alignment of [010] axes subparallel to the lineation is different from the CPO produced by an experimental study (Katayama et al., 2009).

\section{CPOs OF CHLORITE}

Deformation fabrics of chlorite were studied by Kim and Jung (2015) using chlorite peridotites in Amklovdalen, Western Gneiss a. VM1 [100]

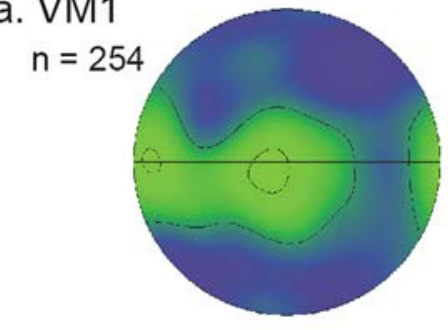

b. VM3

$n=374$

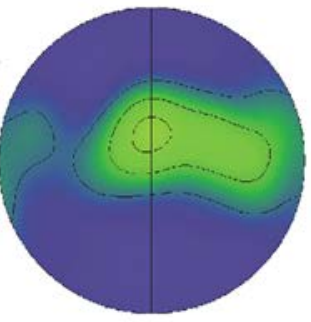

c. $12 \mathrm{~B}$

$n=346$

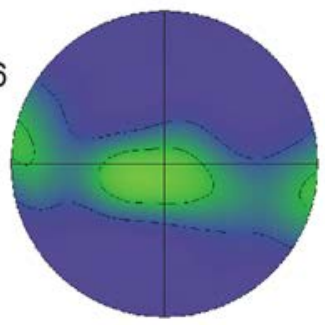

d. $12 \mathrm{M}$

$n=235$

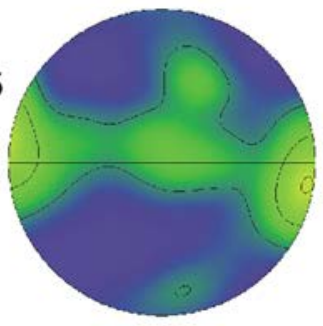

[010]
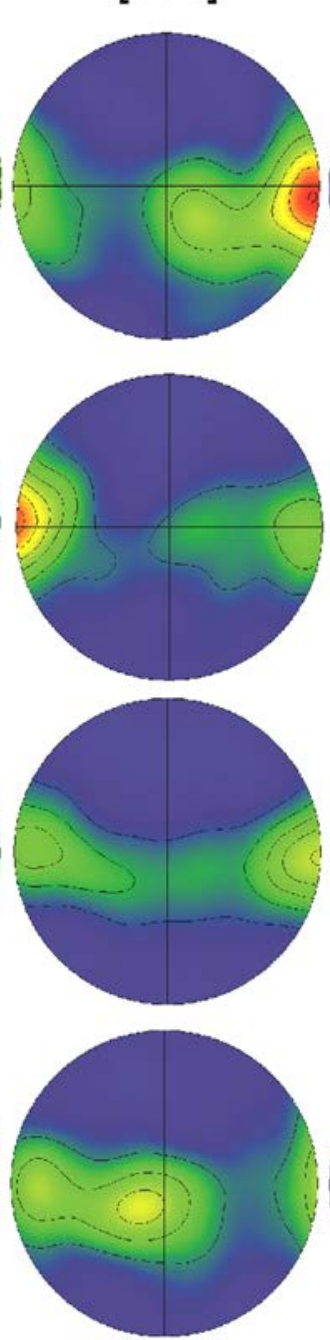
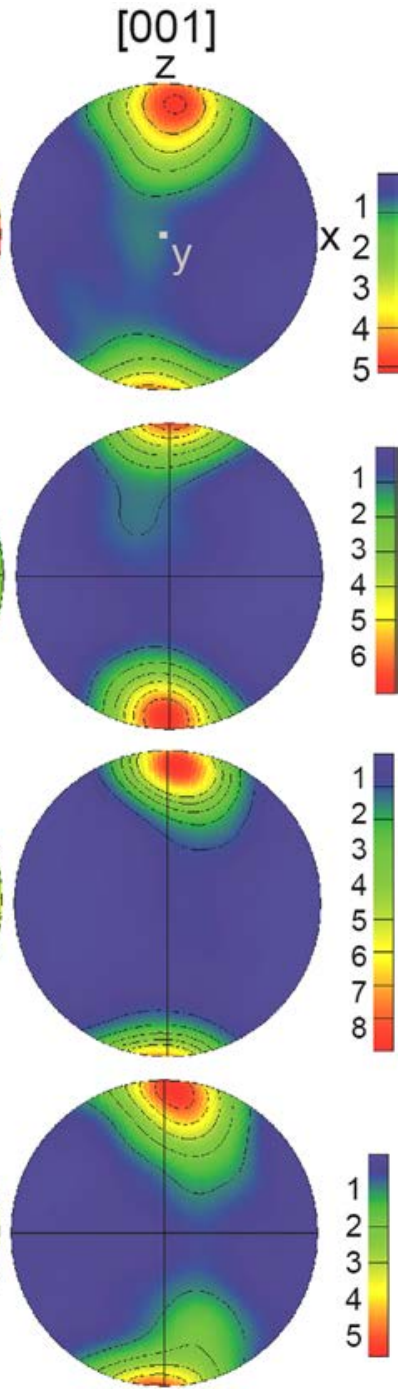

Fig. 10. Typical CPOs of serpentine (antigorite) in serpentinites from Val Malenco ( $a$ and $b$ ) and Punta Bettolina (c and d), northern Italy (Jung, 2011). (a) Sample VM1 consists of Ant: $40 \%$, Ol: 52\%, Di: 5\%, and Mgt: $3 \%$ where Ant: antigorite, Ol: olivine, Di: diopside, and Mgt: magnetite. (b) Sample VM3 consists of Ant: $87 \%$, Ol: $8 \%$, and Mgt: $5 \%$. (c) Sample 12B consists of Ant: 93\%, Ol: $5 \%$, and Mgt: $2 \%$. (d) Sample $12 \mathrm{M}$ consists of Ant: $78 \%$, Ol: $4 \%$, and Mgt: $18 \%$. Pole figures of serpentine are presented in equal-area and lower-hemisphere projections. The E-W direction corresponds to lineation $(\mathrm{x})$. The $\mathrm{N}-\mathrm{S}$ direction $(\mathrm{z})$ represents the direction normal to foliation. The color coding represents the density of the data points. The contours correspond to multiples of a uniform distribution. A half-width of $30^{\circ}$ was used to draw the pole figures. $n$ : number of grains analyzed. 
(a) Type-1 Type-2
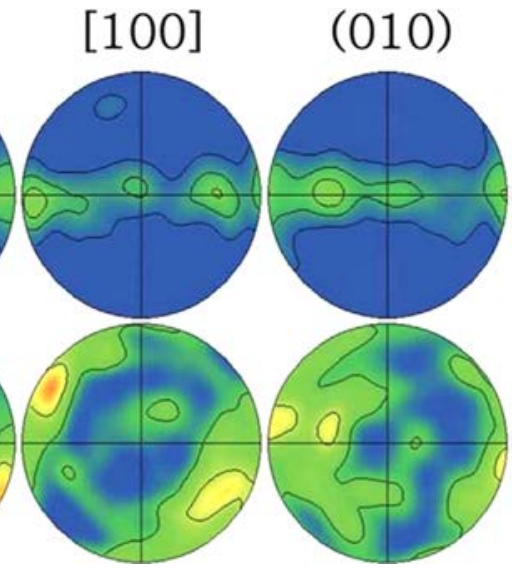

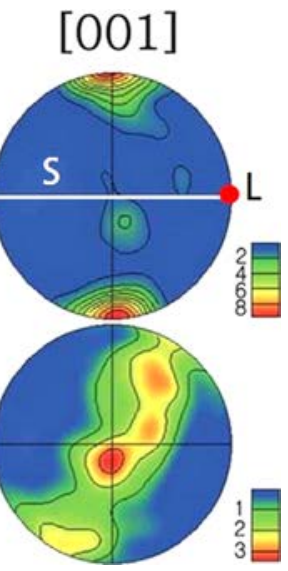

Fig. 11. Typical CPOs of chlorite presented in the lower hemisphere using an equal-area projection (modified from Kim and Jung, 2015). (a) Type-1 CPO of chlorite. Sample 436, N = 302. (b) Type2 CPO of chlorite. Sample 438, N = 395. $\mathrm{N}$ represents the number of grains. The white line (S) indicates the foliation and the red dot $(L)$ indicates the lineation. A half-scatter width of $20^{\circ}$ was used for the contours. The red color represents the high density of data points, and the numbers in the legend correspond to the multiples of uniform distribution.
Region (WGR) in southwest Norway. Two types of chlorite CPOs (Type-1 and -2) were found. Figure 11a shows that chlorite [001] axes are strongly aligned subnormal to foliation and both [100] axes and (010) poles subparallel to foliation. This type of CPO is defined as the Type-1 CPO of chlorite (Kim and Jung, 2015). Figure $11 \mathrm{~b}$ shows that chlorite [001] axes are aligned as a girdle subnormal to the lineation. This type of CPO is defined as the Type-2 CPO of chlorite. Type-1 CPO of chlorite was also observed in natural rocks (Puelles et al., 2012; Morales et al., 2013; Padrón-Navarta et al., 2015; Kang and Jung, submitted). Type-2 CPO of chlorite was less commonly observed and reported in natural samples (Padrón-Navarta et al., 2015; Wallis et al., 2015). The reason for the occurrence of these two chlorite CPO types is currently unknown, and may be a topic of further research.

\section{CPOS OF AMPHIBOLE (HORNBLENDE)}

\subsection{CPOs of Amphibole Experimentally Produced at High Pressure and Temperature}

To understand the CPO development of the amphibole, deformation experiments on amphibole (hornblende) in amphibolite were conducted under simple shear at the high pressure of $1 \mathrm{GPa}$ and temperatures of $480,500,600,700^{\circ} \mathrm{C}$ using the modified Griggs apparatus (Fig. 4b) (Ko and Jung, 2015). The sample was natural amphibolite consisting mainly of hornblende, plagioclase, and minor ilmenite (Fig. 2f). Ko and Jung found three types of amphibole (hornblende) CPOs (Fig. 12a) depending on temperature and stress (Fig. 12b). Type-I CPO of amphibole was found at low temperatures and varied stress conditions. It was characterized as [001] axes aligned subparallel to the shear direction and (100) poles aligned subnormal to the shear plane. Type-II CPO of amphibole was found at an intermediate temperature range $\left(550-700^{\circ} \mathrm{C}\right)$ and high-stress conditions, and characterized as (010) poles aligned subparallel to the shear direction and (100) poles aligned subnormal to the shear plane.
Type-III CPO of amphibole was found at high temperature, low-stress conditions and characterized as both (010) poles and [001] axes aligned subparallel to the shear plane and (100) poles aligned subnormal to the shear plane (Fig. 12).

In a study of amphibole fabric formation during diffusion creep (Getsinger and Hirth, 2014), basalt powder was used as the starting material to which water was added to produce fine-grained amphiboles. Shear deformation experiments were conducted at the pressure of $1 \mathrm{GPa}$ and high temperature of $800^{\circ} \mathrm{C}$. The $\mathrm{CPO}$ of amphibole was characterized as [001] axes aligned subparallel to the shear direction and [100] axes aligned subnormal to the shear plane, which is a Type-I CPO (Fig. 12) (Ko and Jung, 2015).

\subsection{CPOs of Amphibole found in Natural Rocks}

Early studies of the CPO of hornblende were conducted by Schwerdtner (1964) and Mainprice and Nicolas (1989). Amphibole with Type-I CPO was found in many places in the world: lower crustal rocks from the Ivrea Zone, Italy (Barruol and Kern, 1996), Bergell tonalite in the Central Alps (Berger and Stünitz, 1996), amphibolite mylonites from the Diancang Shan in southwest Yunnan, China (Cao et al., 2010), metabasites from the Aracena metamorphic belt in southwest Spain (Díaz Aspiroz et al., 2007), the Lewisian in northwest Scotland, a classic tonalitictrondjhemite-granodioritic (TTG) gneiss complex (Tatham et al., 2008), amphibolites from the East Athabasca mylonite triangle in Saskatchewan, Canada (Ji et al., 2013), and in hornblende schist (Ji et al., 2015). Recent study of amphibole fabric in hydrated peridotites from Bjorkedalen, SW Norway also showed the Type-I CPO of amphibole (Kang and Jung, submitted).

Type-II CPO of amphibole was found in amphibolite mylonites from the Diancang Shan in southwest Yunnan, China (Cao et al., 2010) and in amphibolite in Yeoncheon, South Korea (Jung et al., 2014a). Type-III CPO of amphibole was reported in the Acebuches metabasites in southwestern Spain (Díaz Aspiroz et al., 2007), fine-grained amphibolite from the East Athabasca 


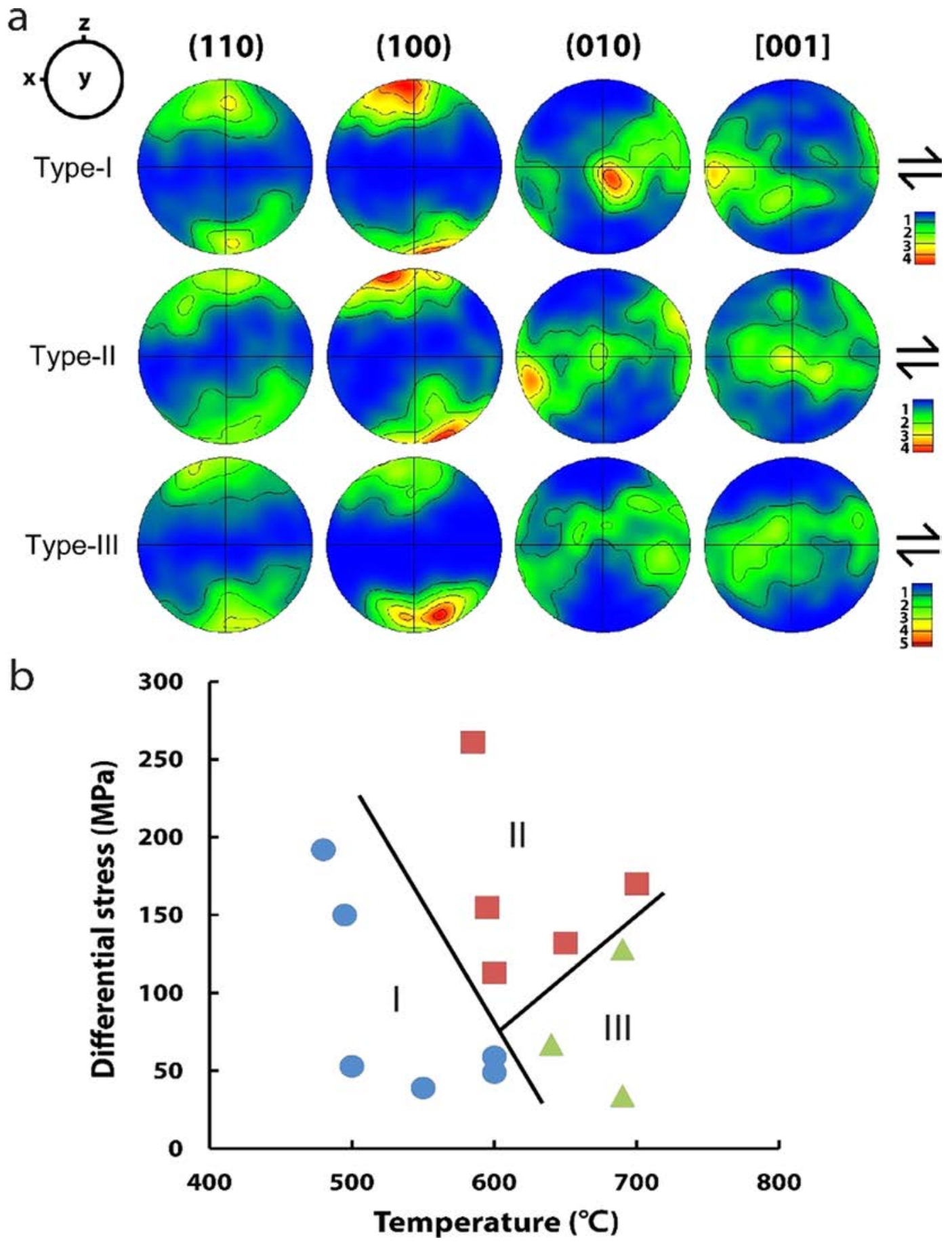

Fig. 12. Pole figures and fabric diagram of amphibole (hornblende). (a) Pole figures of three types of CPOs of the deformed hornblende in simple shear at high pressure and high temperature conditions and (b) their fabric diagram (Ko and Jung, 2015). The $x$ and $z$ direction correspond to the shear direction and the shear plane normal, respectively. The arrows indicate the sense of shear. The pole figures are presented in equal-area and lower-hemisphere projection with a half-width of $20^{\circ}$. The contours indicate the m.u.d. for the density of poles. (Type-I) Sample JH54, $\mathrm{P}=1 \mathrm{GPa}, \mathrm{T}=480^{\circ} \mathrm{C}, \mathrm{n}=202$. (Type-II) Sample JH46, $\mathrm{P}=1 \mathrm{GPa}, \mathrm{T}=600{ }^{\circ} \mathrm{C}, \mathrm{n}=206$. (Type-III) Sample JH74, $\mathrm{P}=1$ $\mathrm{GPa}, \mathrm{T}=640{ }^{\circ} \mathrm{C}, \mathrm{n}=216 . \mathrm{n}$ : number of measured grains. Differential stress: peak value of differential stress after yielding.

mylonite triangle in Saskatchewan, Canada (Ji et al., 2013), and quartz-hornblende-biotite schist (Ji et al., 2015). Type-IV CPO is defined as amphibole [001] axes aligned subparallel to the lineation and both (100) and (110) poles aligned as a girdle subnormal to the lineation. This type of $\mathrm{CPO}$ of amphibole was reported in amphibolites from the Ryoke metamorphic belt in southwest Japan (Imon et al., 2004), metabasites from the Aracena metamorphic belt in southwest Spain (Díaz Aspiroz et al., 2007), 
the Lewisian of northwest Scotland (Tatham et al., 2008), amphibolites in Cabo Ortegal, Spain (Llana-Fúnez and Brown, 2012), retrogressed Limo harzburgites, Limo massif, Cabo Ortegal in northwest Spain (Puelles et al, 2012), and fine-grained amphibolite and clinopyroxene amphibolite from the East Athabasca mylonite triangle in Saskatchewan, Canada (Ji et al., 2013).

\section{Vp Contours $(\mathrm{km} / \mathrm{s})$}
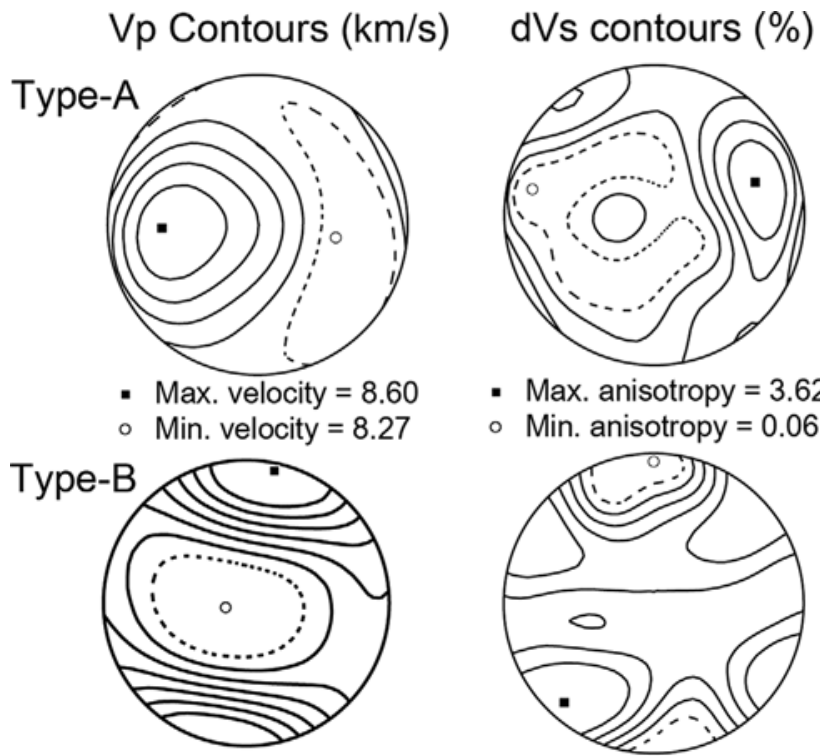

- Max. velocity $=9.00$

- Min. velocity $=8.03$

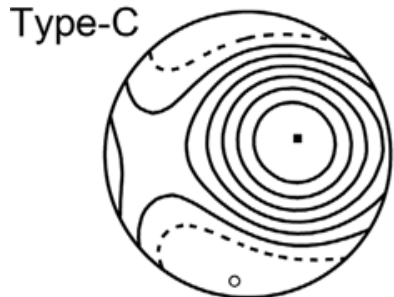

- Max. velocity $=8.93$

- Min. velocity $=8.03$

Type-D

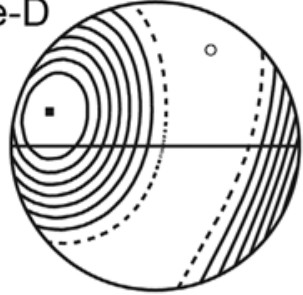

- Max. velocity $=9.05$

- Min. velocity $=8.04$

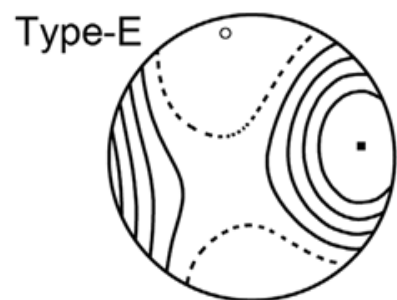

- Max. velocity $=9.02$

○ Min. velocity $=7.60$

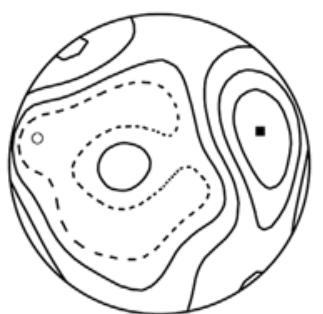

- Max. anisotropy $=3.62$

- Min. anisotropy $=0.06$

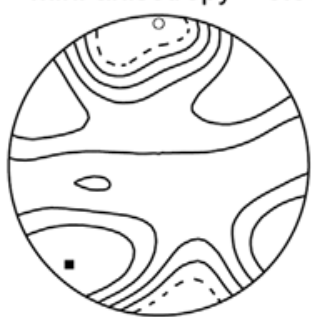

- Max. anisotropy $=7.63$

- Min. anisotropy $=0.06$

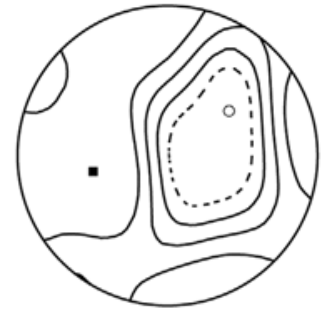

- Max. anisotropy $=6.78$

- Min. anisotropy $=0.16$

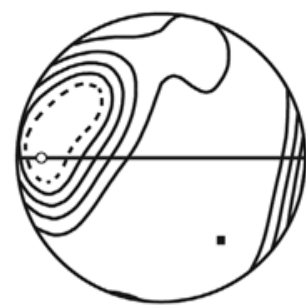

- Max. anisotropy $=7.56$

- Min. anisotropy $=0.16$

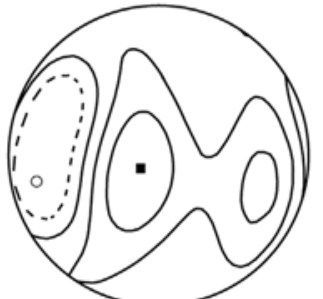

- Max. anisotropy $=12.04$ - Min. anisotropy $=0.54$

\section{GEOPHYSICAL IMPLICATIONS}

Only Type-A CPO of olivine had been used to interpret seismic anisotropy observed in the upper mantle before the paper (Jung and Karato, 2001) was published (Mercier, 1985; Nicolas and Christensen, 1987; Silver, 1996; Savage, 1999;

\section{Vs1 Polarization}
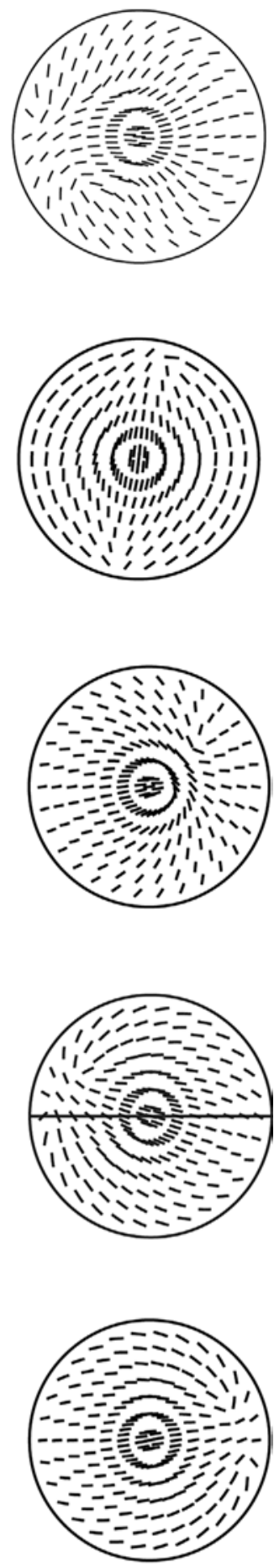

Fig. 13. Seismic anisotropy of olivine for different types of CPOs of olivine in Figure $6 a$ (modified after Jung et al., 2006). Seismic anisotropy is shown on a stereographic projection in which the center of a plot is the direction normal to the shear plane, and the E-W direction corresponds to the shear direction. P-wave anisotropy, the amplitude of shear wave splitting (dVs) and the direction of polarization of the faster shear wave (Vs1) are shown. 
Mainprice et al., 2000; Smith et al., 2001) because no other types of olivine CPOs were known at that time. However, there were difficulties in explaining seismic anisotropies observed in collision zones and hotspot regions such as Hawaii using the Type-A CPO of olivine (Jung and Karato, 2001; Park and Levin, 2002). The seismic velocities and anisotropies of different types of olivine CPOs are shown in Figure 13. Type-B, -C, -D, -E CPOs of olivine produce different seismic signatures from Type-A CPO (Fig. 13) (see also Jung et al., 2006; Karato et al., 2008). The water content of olivine in the mid-ocean ridge basalt (MORB), originating from the oceanic asthenosphere, was reported as 500-1,000 ppm H/Si (Hirth and Kohlstedt, 1996). In addition, a higher water content exists in basalt originating from hotspots (Wallace, 1998; Jamtveit et al., 2001). Therefore, the anomalous seismic anisotropy observed below hotspots (Montagner and Guillot, 2000; Gaherty, 2001), can be explained by water-induced
Type-C CPO of olivine. Seismic anisotropies produced by the four orthopyroxene CPOs are shown in Figure 14; their seismic signatures are also different (Jung et al., 2010). The seismic properties of orthopyroxene should be carefully considered to better understand the overall seismic anisotropy in subduction zones.

Seismic anisotropy of the P- and S-wave was observed in the mantle wedge in many subduction zones worldwide (i.e., Fig. 1) (Savage, 1999; Park and Levin, 2002; Long and Silver, 2008; Long, 2013; Long and Wirth, 2013; Wang and Zhao, 2013; Zhao et al., 2016). Trench-parallel seismic anisotropy of the fast Swave was observed in many fore-arc areas and sub-slabs in subduction zones (Ando et al., 1983; Fouch and Fischer, 1996; Margheriti et al., 1996; Smith et al., 2001; Nakajima and Hasegawa, 2004; Long and van der Hilst, 2005; Abt et al., 2010; Long and Becker, 2010; Di Leo et al., 2012; Long and Wirth, 2013; Wagner
Vp Contours $(\mathrm{km} / \mathrm{s})$

Type-AB

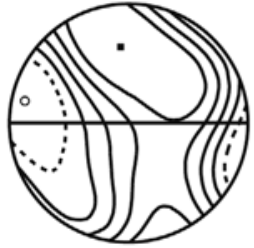

Max. Velocity $=8.22$

$O$ Min. Velocity $=8.06$

Anisotropy $=1.9 \%$

Type-AC

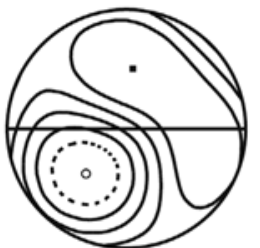

Max. Velocity $=8.28$

$O$ Min. Velocity $=7.95$ Anisotropy $=4.1 \%$

Type-BC

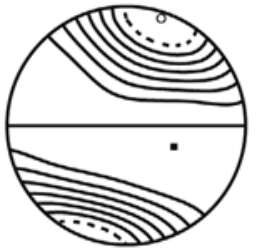

- Max. Velocity $=8.30$

O Min. Velocity $=7.82$ Anisotropy $=5.9 \%$

Type-ABC

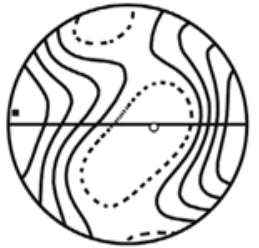

- Max. Velocity $=8.23$

O Min. Velocity $=8.08$

Anisotropy $=1.8 \%$
AVs Contours (\%)

\section{Vs1 Polarization}

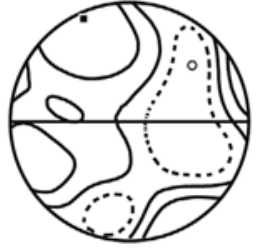

Max. Anisotropy $=2.96$

$\mathrm{O}$ Min.Anisotropy $=0.04$

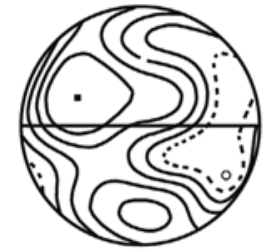

- Max.Anisotropy $=3.97$

$O \mathrm{Min}$. Anisotropy $=0.18$

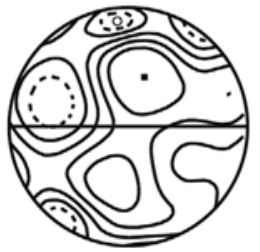

Max.Anisotropy $=3.95$

0 Min. Anisotropy $=0.04$

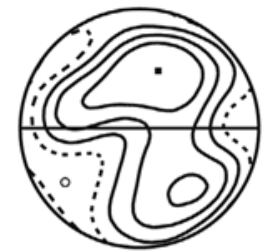

Max. Anisotropy $=3.39$

0 Min.Anisotropy $=0.14$
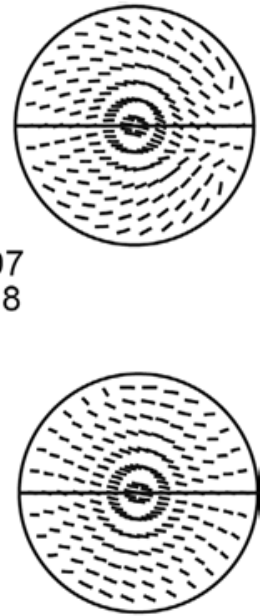

Fig. 14. Seismic anisotropy of orthopyroxene for different types of CPOs of orthopyroxene in Figure 9 (after Jung et al., 2010). The east-west direction corresponds to the lineation (L), and the north-south corresponds to the foliation normal. Azimuthal anisotropy of Pwaves (Vp) and polarization anisotropy of S-waves are shown (AVs is a contour plot of the magnitude of shear wave polarization anisotropy and Vs 1 is a plot of the polarization direction of fast $\mathrm{S}$ propagation). waves along different orientations of 
et al., 2013; Lynner and Long, 2014). The source of this trenchparallel seismic anisotropy was proposed as: (1) the trenchparallel mantle flow due to trench-roll back (Russo and Silver, 1994; Long and Silver, 2008; Long and Silver, 2009); (2) Type-B
CPO of olivine (Jung and Karato, 2001; Kneller et al., 2005; Jung et al., 2006; Katayama and Karato, 2006; Kneller and van Keken, 2007; Karato et al., 2008); (3) the 3-D mantle flow around the slab (Faccenda and Capitanio, 2012, 2013; Li et al., 2014; Lynner
Vp Contours $(\mathrm{km} / \mathrm{s})$

a. VM1

Ant $40 \%$

Mgt 3\%

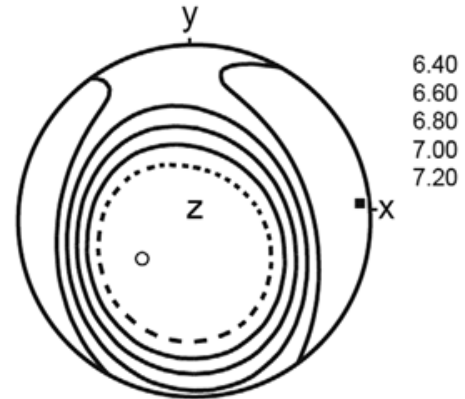

- Max.Velocity $=7.70 \quad$ oMin.Velocity $=6.08$ Anisotropy $=23.6 \%$

b. VM3

Ant $87 \%$

Mgt 5\%

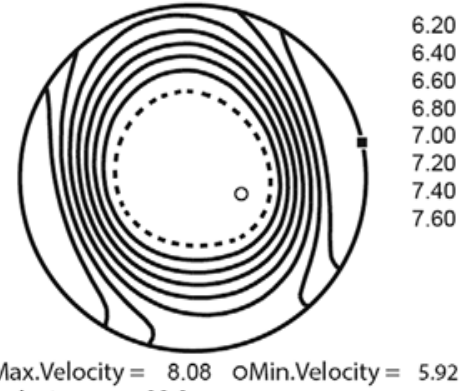
Anisotropy $=30.8 \%$

c. $12 \mathrm{~B}$

Ant $93 \%$

Mgt $2 \%$

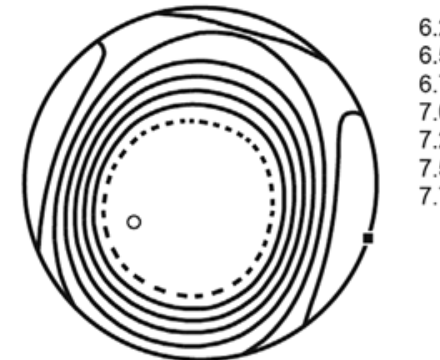

- Max.Velocity $=8.12 \quad$ OMin.Velocity $=5.92$ Anisotropy $=31.4 \%$

d. $12 \mathrm{M}$

Ant $78 \%$

Mgt $18 \%$

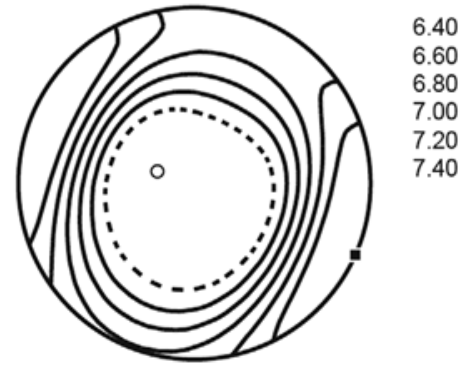

- Max.Velocity $=7.82$ oMin. Velocity $=6.08$ Anisotropy $=25.0 \%$
AVs Contours (\%)

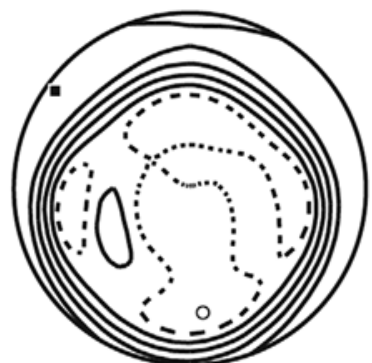

6.0

9.0
12.0

15.0

18.0

- Max.Anisotropy $=23.20$ oMin.Anisotropy $=.23$

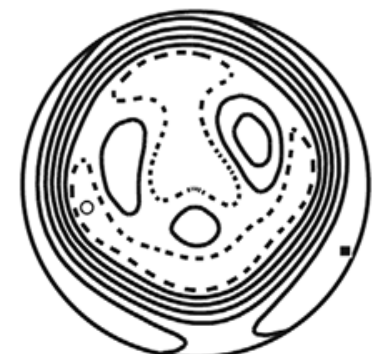

8.0

12.0

16.0

20.0

24.0

- Max.Anisotropy $=34.01$ OMin.Anisotropy $=.15$

Vs1 Polarization
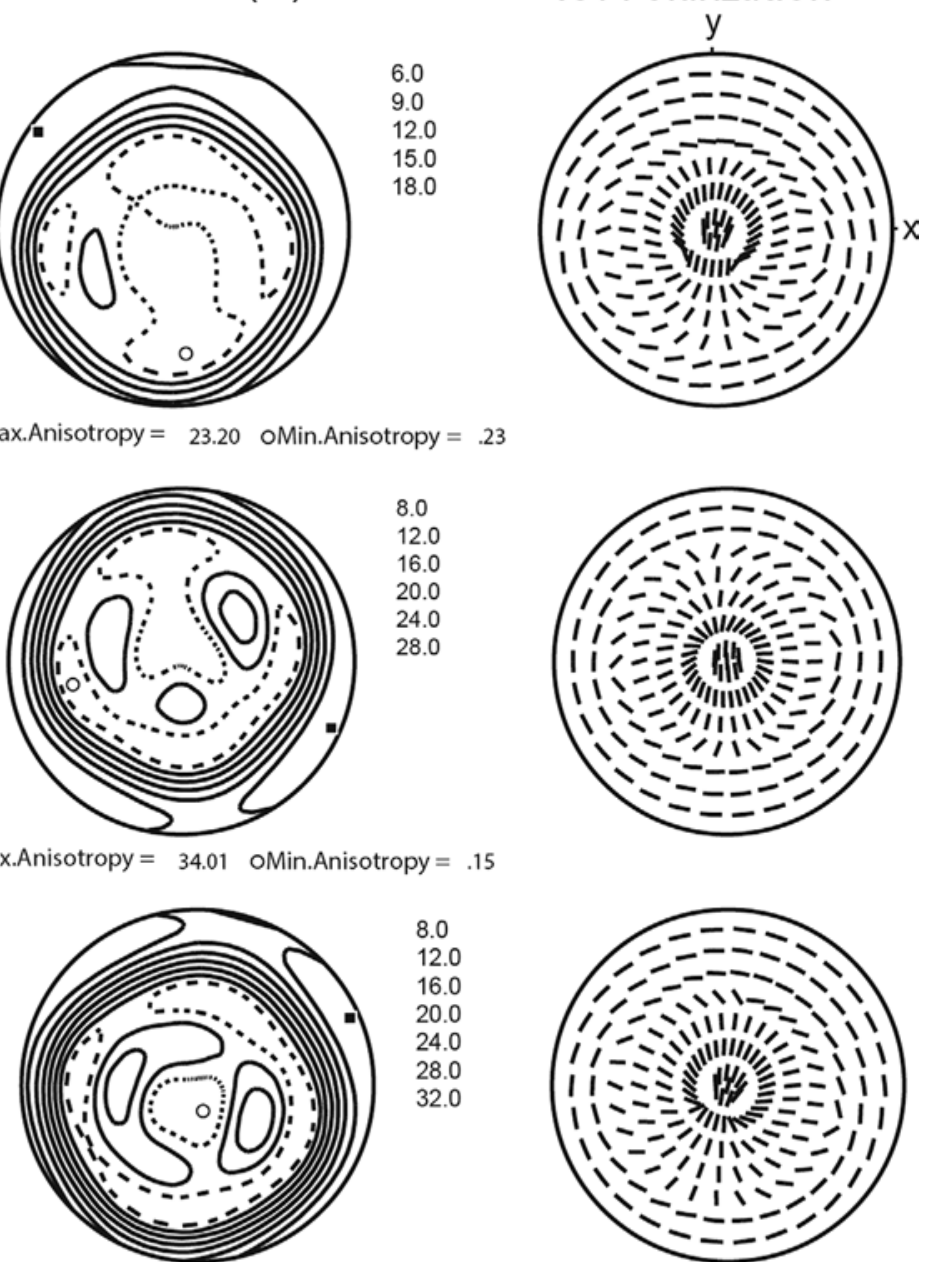

8.0

12.0

20.0

28.0

32.0

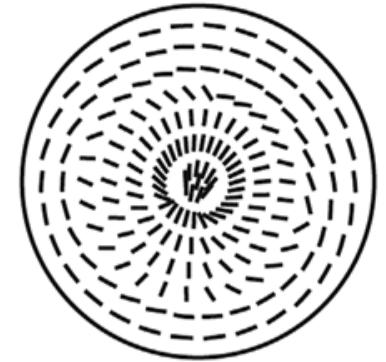

- Max.Anisotropy $=36.53$ oMin.Anisotropy $=.31$

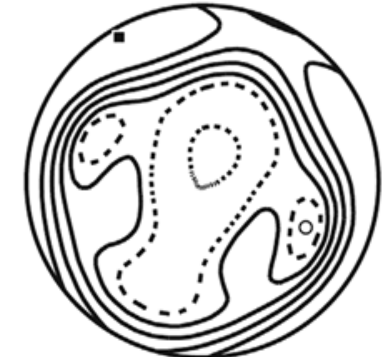

6.0

9.0

12.0

18.0

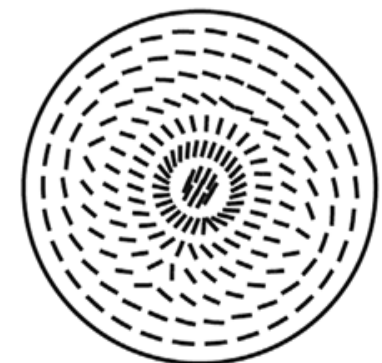

Fig. 15. Seismic anisotropy of serpentine which was calculated from the CPOs of serpentine in Figure 10. The effects of the degree of serpentinization and composition on seismic anisotropy are shown in equal-area and lower hemisphere projections (from Jung, 2011). The seismic anisotropy of serpentine in all the samples is shown in the horizontal flow, where the $\mathrm{Y}$ and $\mathrm{Z}$ axes are rotated $90^{\circ}$ relative to Figure 10. The X-direction corresponds to the direction of lineation (flow direction). The Z-direction represents the direction normal to foliation (flow plane). The compressional-wave velocity ( $\mathrm{Vp}$ ) and shear-wave anisotropy (AVs) are shown. Vs1 is a plot of the polarization direction of fast S-waves along different orientations of propagation. The center of the stereonet corresponds to vertical propagation. For the vertical propagation of S-waves, the polarization direction of fast S-waves is nearly perpendicular to the flow direction (lineation). Ant: antigorite, Mgt: magnetite. 
et al., 2017); (4) fault or crack-induced anisotropy in the slab (Faccenda et al., 2008; Healy et al., 2009); (5) strong radial anisotropy (Song and Kawakatsu, 2012, 2013); (6) CPO of serpentine in the slab-mantle interface and in the mantle wedge (Katayama et al., 2009; Jung, 2011; Nagaya et al., 2016); and (7) CPOs of chlorite (Kim and Jung, 2015; Kang and Jung, submitted) and amphibole in the lower part of mantle wedge (Ko and Jung, 2015; Kang and Jung, submitted). Since olivine in the mantle wedge is hydrated by the fluids from the dehydration of minerals in the subducting slab (Peacock and Hyndman, 1999; van Keken et al., 2011), and the stress is high in a collision zone in the subduction zones, it is highly likely that Type-B CPO of olivine is formed in the mantle wedge. This hypothesis is supported by numerical modeling studies of the effect of Type-B olivine CPO on seismic anisotropy in the subduction zone (Kneller et al., $2005,2007)$. It is also supported by many observations of TypeB olivine CPOs in mantle xenoliths (Park and Jung, 2015) and peridotites in subduction zone settings (Table 3) (Mizukami et al., 2004; Skemer et al., 2006; Tasaka et al., 2008; Jung, 2009; Jung et al., 2014b; Kim and Jung, 2015; Behr and Smith, 2016).

It is interesting to see the changes in seismic anisotropy patterns; from trench-parallel S-wave anisotropy in the fore-arc area to the trench-normal S-wave anisotropy in the back-arc area (Smith et al., 2001; Nakajima and Hasegawa, 2004; Long and van der Hilst, 2006; Long and Wirth, 2013). This pattern of seismic anisotropy may be explained by the change in olivine $\mathrm{CPO}$ from Type-B in the fore-arc to Type-A, -C (or -E) in the back-arc (Kneller et al., 2005; Katayama and Karato, 2006; Kneller et al., 2007; Karato et al., 2008; Jung, 2012). The trench-parallel seismic anisotropy was also observed in the subducting slab and below the slab at a depth greater than $100 \mathrm{~km}$ in the subduction zone (Russo and Silver, 1994; Müller et al., 2008; Long and Silver, 2009; Abt et al., 2010; Di Leo et al., 2014; Lynner and Long, 2014; Lynner et al., 2017). Because of the relatively dry conditions below the slab (Karato et al., 2008), one possible explanation of this seismic anisotropy is the Type- $\mathrm{B}$ olivine CPO that can be produced by high pressure in dry conditions (Jung et al., 2009b; Ohuchi et al., 2011; Soustelle and Manthilake, 2017). This is supported by a recent study on Type-B olivine CPOs found in diamond-bearing peridotites in Finsch, South Africa (Lee and Jung, 2015), which is the first report of a natural example of pressure-induced Type-B CPO of olivine.

In addition, anomalously long delay times (1-4 s) of S-waves and strong trench-parallel anisotropy have been observed in some subduction zones such as in the Ryukyu, Izu-Bonin, and Tonga-Kermadec arcs (Smith et al., 2001; Anglin and Fouch, 2005; Long and van der Hilst, 2005; Greve et al., 2008). This strong seismic anisotropy may be caused by the strong CPOs of hydrous minerals in the lower part of the mantle wedge and at the interface between slab and mantle wedge. Hydrous minerals

\section{(a) Low angle (warm) subduction zone}

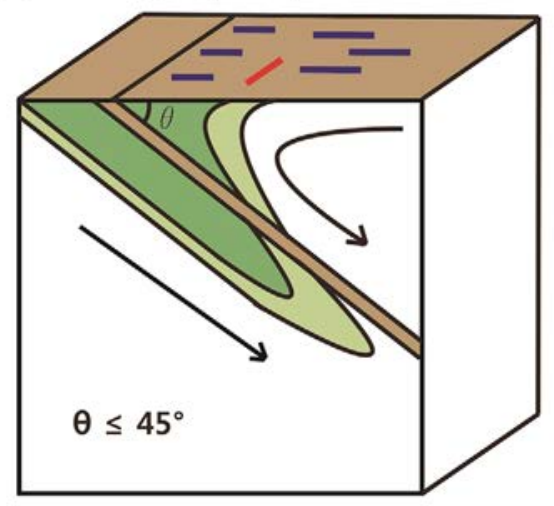

(c) Angle-changing subduction zone

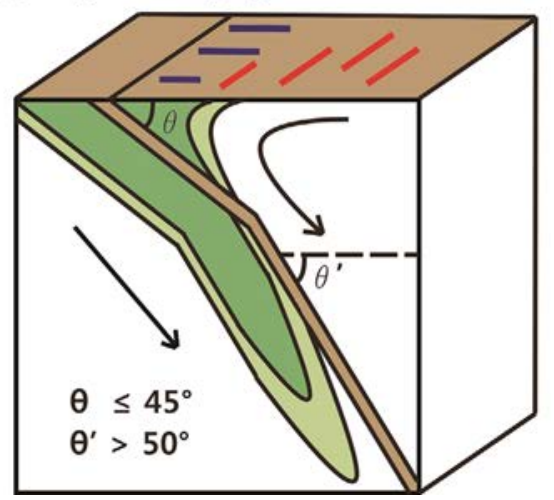

(b) High angle (cold) subduction zone

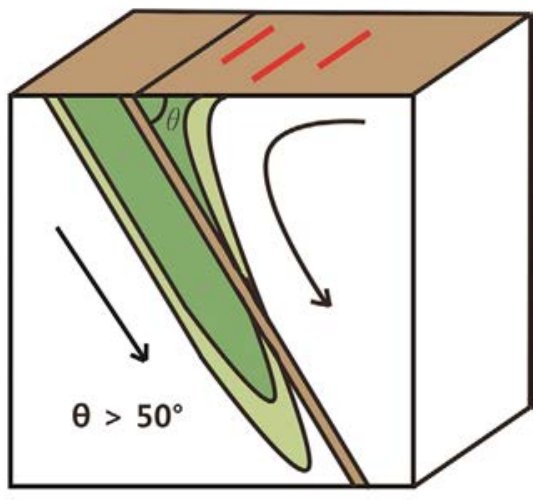

Serpentine stability

Chlorite stability

Slab crust

Trench-normal seismic anisotropy

Trench-parallel seismic anisotropy
Fig. 16. Schematic diagram showing the effect of the dipping angle of the slab on the seismic anisotropy caused by the CPO of chlorite (Fig. 11a), assuming 2-D corner flow (from Kim and Jung, 2015). (a) Trench-normal seismic anisotropy in the low-angle subduction zone $\left(\theta \leq 45^{\circ}\right)$. (b) Trench-parallel seismic anisotropy in the high-angle subduction zone $\left(\theta>50^{\circ}\right)$. (c) Change in the seismic anisotropy corresponding to the change in the dipping angle of the slab. Blue and red bars represent trench-normal and trench-parallel seismic anisotropy of the fast S-wave, respectively. (a) Low-angle (warm) subduction zone. (b) High-angle (cold) subduction zone. (c) Angle-changing subduction zone. 
such as serpentine, chlorite, and amphibole can be stable at high pressure and temperature conditions down to $\sim 200 \mathrm{~km}$ (Ulmer and Trommsdorff, 1995; Pawley, 2003; Fumagalli and Poli, 2005). Shear deformation experiments of those hydrous minerals produce strong CPOs at high pressures (Katayama et al., 2009; Ko and Jung, 2015). Recent studies on the deformation fabrics of hydrous minerals (serpentine, chlorite, and amphibole) also showed that strong CPOs of the hydrous minerals in natural rocks are formed (Figs. 10 and 11) and the CPOs of those serpentine, chlorite, and ampibole can produce a strong trench-parallel seismic anisotropy (Figs. 15, 16, and 17b) (Jung, 2011; Kim and Jung, 2015; Ko and Jung, 2015; Kang and Jung, submitted) and long delay times of S-waves (Fig. 18). The seismic velocity and anisotropy pattern of serpentine, chlorite, and amphibole were investigated in detail (Figs. 15-17), revealing that the strong trench-parallel seismic anisotropy in the slab and at the slabmantle interface where the hydrous minerals are stable can be explained by the CPOs of the hydrous minerals when the subduction angle of the slab is high $\left(\theta \geq 45^{\circ}\right)$ (Jung, 2011; Kim and Jung, 2015; Ko and Jung, 2015). Figure 18 shows the thickness (L) of the anisotropic layer (i.e., antigorite, chlorite, hornblende, and olivine) that explains a wide range of delay times (dt) of Swaves. The figure shows that long delay times (large seismic anisotropy) of S-waves in some subduction zones can be explained by a thin anisotropic layer of hydrous minerals such as chlorite, antigorite, and hornblende.

\section{a Hb horizontal flow}

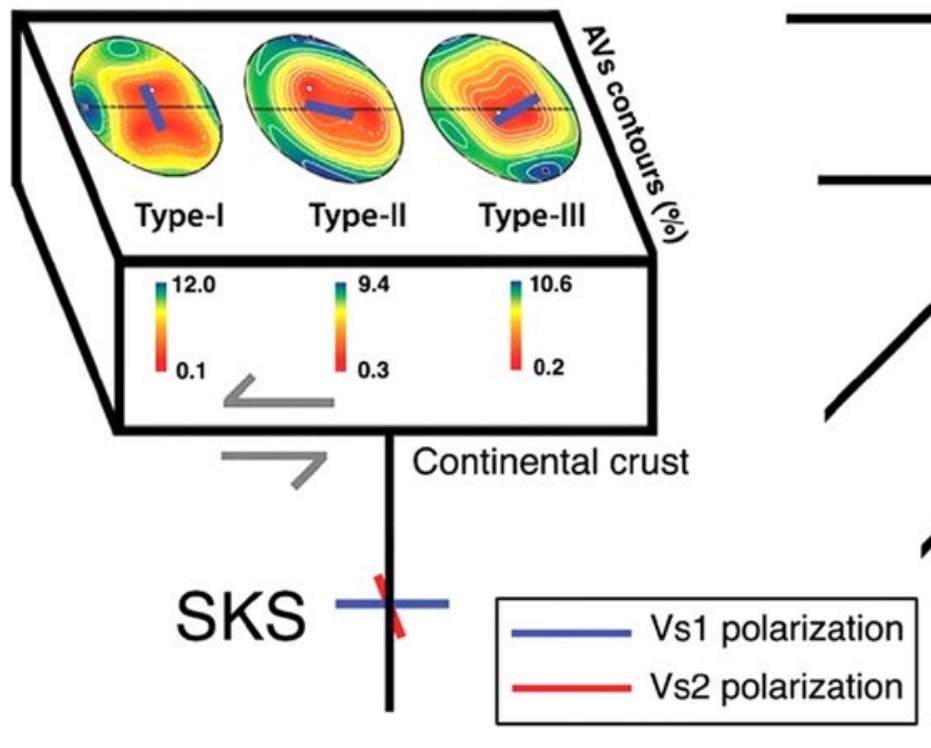

Fig. 17. Seismic signatures from three different CPO types of amphibole are shown in (a) continental crust and (b) subduction zone (from Ko and Jung, 2015). (a) For horizontal flow in the continental crust, the anisotropy contours of the S-waves (AVs) show that the orientation of high anisotropy depends on the CPO types of amphibole. (b) For the flow dipping at $45^{\circ}$ in the subduction zone, seismic anisotropy is strong, and the Vs1 polarization direction (blue bar) is parallel to the trench for all three CPO types of amphibole for a vertically propagating S-wave (SKS). The blue and red bars indicate the polarization directions of the fast shear wave (Vs1) and slow shear wave (Vs2), respectively. $\mathrm{Hb}$, hornblende.

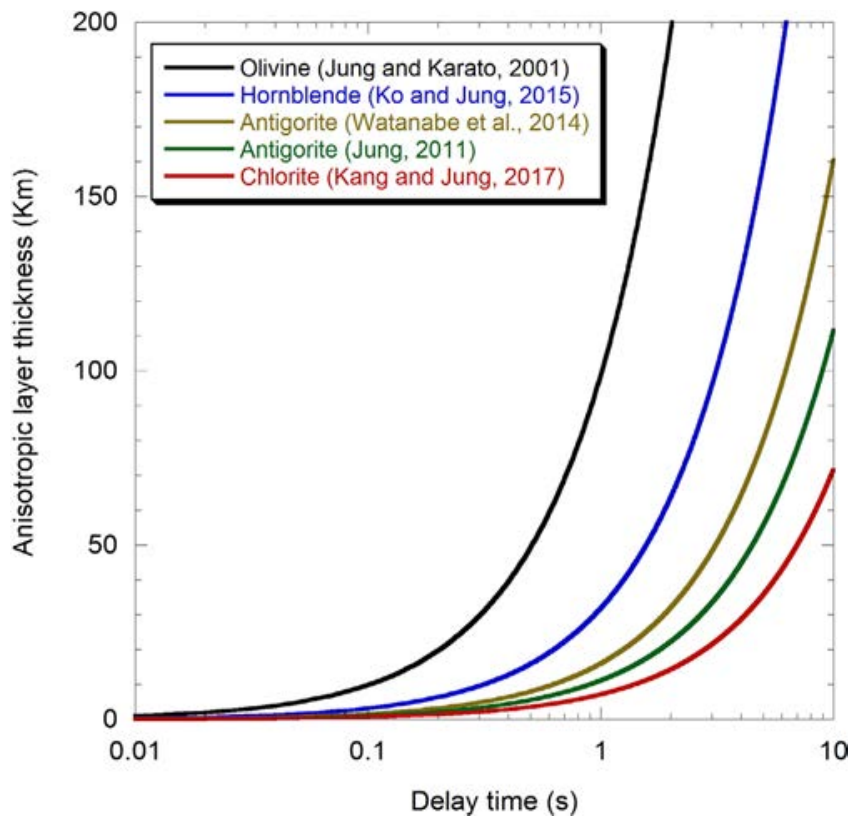

Fig. 18. A diagram showing the relationship between delay time $(\mathrm{dt})$ and anisotropic layer thickness (L) of individual mineral. The following equation (Silver and Chan, 1991; Mainprice and Silver, 1993) was used: $\mathrm{dt} / \mathrm{L}=\mathrm{AVs} /\langle\mathrm{Vs}\rangle$, where $\mathrm{dt}$ is the delay time of the shear waves, $\mathrm{AVs}$ is the anisotropy of the $\mathrm{S}$-wave for a specific propagation direction, and $\langle\mathrm{Vs}\rangle$ is the average velocity of the fast and slow S-wave velocities. To calculate delay time, seismic anisotropy data of olivine (sample JK8; AVs $=5 \%$ ) (Jung and Karato, 2001), antigorite (sample VM3; AVs = 34\%) (Jung, 2011), antigorite (sample HKB-B; AVs = 24\%) (Watanabe et al., 2014), chlorite (sample 1194-2; AVs $=46 \%$ ) (Kang and Jung, 2015) were used.

\section{b $\mathrm{Hb}$ flow dipping at $45^{\circ}$}

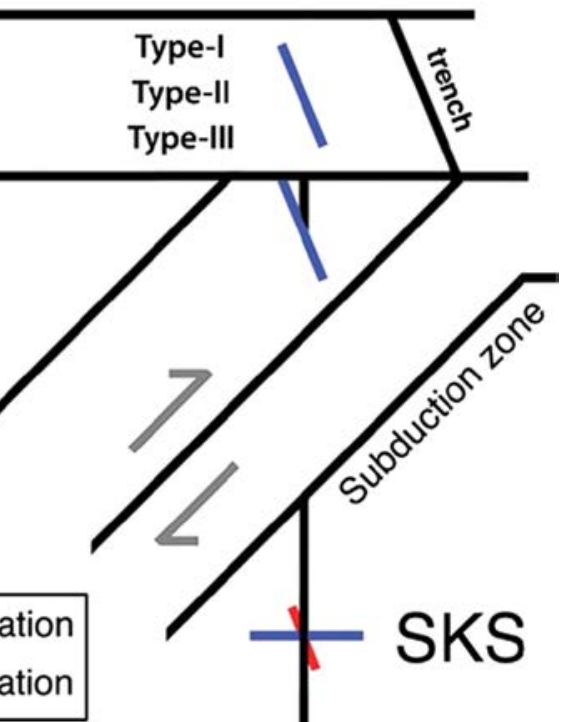
and Jung, submitted), and hornblende (sample JH65; AVs = 12\%) (Ko 
A part of seismic anisotropy in subduction zones can be attributed to the other hydrous minerals such as glaucophane, lawsonite, and epidote in subducting slabs. There are some previous reports on the study of $\mathrm{CPO}$ and resultant seismic anisotropy of glaucophane (Cao et al., 2013; Kim et al., 2013; Cao and Jung, 2016; Ha et al., 2018), lawsonite (Kim et al., 2013, 2016; Cao et al., 2014; Cao and Jung, 2016), and epidote (Cao et al., 2011, 2013; Ha et al., 2018). However, these data are very limited so far and more detail studies on the development of CPOs of those minerals and resultant seismic signatures are needed to better understand the seismic anisotropy in the subducting slabs.

\section{CONCLUSIONS}

Crystal preferred orientations (CPOs) of olivine, orthopyroxene, serpentine, chlorite, and amphibole in previous experimental research and in natural rocks were reviewed, and the seismic anisotropies of those minerals were discussed. Water-induced CPOs of olivine, such as Type-B, - $\mathrm{C}$, and -E found in experimental studies, were also observed in many natural rocks and could be very important for interpreting seismic anisotropies in the upper mantle. Hydrous minerals such as amphibole, chlorite, and serpentine in the lower part of the mantle wedge and at the slabmantle interface can also produce strong CPOs, which can be used to interpret anomalously strong seismic anisotropies in some subduction zones. In the future, hydrous minerals in the subducting slab (i.e., glaucophane, epidote, and lawsonite) should be investigated in detail to better understand the seismic anisotropy in the slab in subduction zones.

\section{ACKNOWLEDGMENTS}

H.J. would like to thank colleagues at the Tectonophysics Laboratory at the Seoul National University and other institutions for their help in various projects. H.J. wishes to thank Y. Park and S. Jung for preparing Tables and S. Choi for his help in preparing Figure 3. H.J. would also like to express sincere gratitude to Dr. Simon Wallis and an anonymous reviewer for their valuable comments and suggestions. This study was supported by the NRF grant of Korea (NRF-2017R1A2B2004688) and by KMIPA20179020.

\section{REFERENCES}

Abramson, E.H., Brown, J.M., Slutsky, L.J., and Zaug, J., 1997, The elastic constants of San Carlos olivine to $17 \mathrm{GPa}$. Journal of Geophysical Research: Solid Earth, 102, 12253-12263.

Abt, D.L., Fischer, K.M., Abers, G.A., Protti, M., González, V., and
Strauch, W., 2010, Constraints on upper mantle anisotropy surrounding the Cocos slab from SK(K)S splitting. Journal of Geophysical Research: Solid Earth, 115, B06316.

Aleksandrov, K., Alchikov, U., Belikov, B., Zaslavskii, B., and Krupnyi, A., 1974, Velocities of elastic waves in minerals at atmospheric pressure and increasing precision of elastic constants by means of EVM. Izvestiya Akademii Nauk SSSR, Seriya Geologicheskaya, 10, 15-24. (in Russian)

Aleksandrov, K.S. and Ryzhova, T.V., 1961a, The elastic properties of rock-forming minerals, I: pyroxenes and amphiboles. Bulletin of the Academy of Sciences of the USSR: Geophysics series, 871-875, 1339-1344.

Aleksandrov, K. and Ryzhova, T., 1961b, Elastic properties of rockforming minerals II: layered silicates. Bulletin of the Academy of Sciences of the USSR: Geophysics series, English translation, 12, $1165-1168$

Almqvist, B.S.G. and Mainprice, D., 2017, Seismic properties and anisotropy of the continental crust: predictions based on mineral texture and rock microstructure. Reviews of Geophysics, 55, 367433.

Ando, M., Ishikawa, Y., and Yamazaki, F., 1983, Shear wave polarization anisotropy in the upper mantle beneath Honshu, Japan. Journal of Geophysical Research, 88, 5850-5864.

Anglin, D.K. and Fouch, M.J., 2005, Seismic anisotropy in the IzuBonin subduction system. Geophysical Research Letters, 32, L09307. doi:10.1029/2005GL022714

Auzende, A.-L., Pellenq, R.-M., Devouard, B., Baronnet, A., and Grauby, O., 2006, Atomistic calculations of structural and elastic properties of serpentine minerals: the case of lizardite. Physics and Chemistry of Minerals, 33, 266-275.

Avé Lallemant, H.G. and Carter, N.L., 1970, Syntectonic recrystallization of olivine and modes of flow in the upper mantle. Bulletin of the Geological Society of America, 81, 2203-2220.

Barruol, G. and Kern, H., 1996, Seismic anisotropy and shear-wave splitting in lower-crustal and upper-mantle rocks from the Ivrea Zone - experimental and calculated data. Physics of the Earth and Planetary Interiors, 95, 175-194.

Behr, W.M. and Smith, D., 2016, Deformation in the mantle wedge associated with Laramide flat-slab subduction. Geochemistry, Geophysics, Geosystems, 17, 2643-2660.

Ben Ismail, W. and Mainprice, D., 1998, An olivine fabric database: an overview of upper mantle fabrics and seismic anisotropy. Tectonophysics, 296, 145-157.

Berger, A. and Stünitz, H., 1996, Deformation mechanisms and reaction of hornblende: examples from the Bergell tonalite (Central Alps). Tectonophysics, 257, 149-174.

Bezacier, L., Reynard, B., Bass, J.D., Sanchez-Valle, C., and Van de Moortele, B.V., 2010, Elasticity of antigorite, seismic detection of serpentinites, and anisotropy in subduction zones. Earth and Planetary Science Letters, 289, 198-208.

Birch, F., 1960, The velocity of compressional waves in rocks to 10 kilobars: 1. Journal of Geophysical Research, 65, 1083-1102.

Boneh, Y., Morales, L.F.G., Kaminski, E., and Skemer, P., 2015, Modeling olivine $\mathrm{CPO}$ evolution with complex deformation histories: implications for the interpretation of seismic anisotropy in the 
mantle. Geochemistry, Geophysics, Geosystems, 16, 3436-3455.

Boneh, Y. and Skemer, P., 2014, The effect of deformation history on the evolution of olivine CPO. Earth and Planetary Science Letters, 406, 213-222.

Brown, J.M. and Abramson, E.H., 2016, Elasticity of calcium and calcium-sodium amphiboles. Physics of the Earth and Planetary Interiors, 261, 161-171.

Brownlee, S.J., Hacker, B.R., Harlow, G.E., and Seward, G., 2013, Seismic signatures of a hydrated mantle wedge from antigorite crystalpreferred orientation (CPO). Earth and Planetary Science Letters, 375, 395-407.

Bystricky, M., Kunze, K., Burlini, L., and Burg, J.P., 2000, High shear strain of olivine aggregates: rheological and seismic consequences. Science, 290, 1564-1567.

Cao, S., Liu, J., and Leiss, B., 2010, Orientation-related deformation mechanisms of naturally deformed amphibole in amphibolite mylonites from the Diancang Shan, SW Yunnan, China. Journal of Structural Geology, 32, 606-622.

Cao, Y. and Jung, H., 2016, Seismic properties of subducting oceanic crust: constraints from natural lawsonite-bearing blueschist and eclogite in Sivrihisar Massif, Turkey. Physics of the Earth and Planetary Interiors, 250, 12-30.

Cao, Y., Jung, H., and Song, S., 2013, Petro-fabrics and seismic properties of blueschist and eclogite in the North Qilian suture zone, NW China: implications for the low-velocity upper layer in subducting slab, trench-parallel seismic anisotropy, and eclogite detectability in the subduction zone. Journal of Geophysical Research: Solid Earth, 118, 3037-3058.

Cao, Y., Jung, H., and Song, S., 2014, Microstructures and petro-fabrics of lawsonite blueschist in the North Qilian suture zone, NW China: implications for seismic anisotropy of subducting oceanic crust. Tectonophysics, 628, 140-157.

Cao, Y., Jung, H., and Song, S.G., 2017, Olivine fabrics and tectonic evolution of fore-arc mantles: a natural perspective from the Songshugou dunite and harzburgite in the Qinling orogenic belt, central China. Geochemistry, Geophysics, Geosystems, 18, 907-934.

Cao, Y., Jung, H., Song, S.G., Park, M., Jung, S., and Lee, J., 2015, Plastic deformation and seismic properties in fore-arc mantles: a petrofabric analysis of the Yushigou Harzburgites, North Qilian Suture Zone, NW China. Journal of Petrology, 56, 1897-1943.

Cao, Y., Song, S.G., Niu, Y.L., Jung, H., and Jin, Z.M., 2011, Variation of mineral composition, fabric and oxygen fugacity from massive to foliated eclogites during exhumation of subducted ocean crust in the North Qilian suture zone, NW China. Journal of Metamorphic Geology, 29, 699-720.

Carter, N.L. and Avé Lallemant, H.G., 1970, High temperature flow of dunite and peridotite. Bulletin of the Geological Society of America, 81, 2181-2202.

Castelnau, O., Blackman, D.K., and Becker, T.W., 2009, Numerical simulations of texture development and associated rheological anisotropy in regions of complex mantle flow. Geophysical Research Letters, 36, L12304. doi:10.1029/2009GL038027

Castelnau, O., Blackman, D.K., Lebensohn, R.A., and Ponte Castañeda, P., 2008, Micromechanical modeling of the viscoplastic behavior of olivine. Journal of Geophysical Research: Solid Earth, 113, B09202.
doi:10.1029/2007JB005444

Castelnau, O., Cordier, P., Lebensohn, R.A., Merkel, S., and Raterron, P., 2010, Microstructures and rheology of the Earth's upper mantle inferred from a multiscale approach. Comptes Rendus Physique, $11,304-315$.

Chai, M., Brown, J.M., and Slutsky, L.J., 1997, The elastic constants of an aluminous orthopyroxene to $12.5 \mathrm{GPa}$. Journal of Geophysical Research: Solid Earth, 102, 14779-14785.

Chatzaras, V., Kruckenberg, S.C., Cohen, S.M., Medaris, L.G., Jr., Withers, A.C., and Bagley, B., 2016, Axial-type olivine crystallographic preferred orientations: the effect of strain geometry on mantle texture. Journal of Geophysical Research: Solid Earth, 121, 4895-4922.

Christensen, N.I. and Lundquist, S.M., 1982, Pyroxene orientation within the upper mantle. Geological Society of America Bulletin, 93, 279288.

Couvy, H., Frost, D.J., Heidelbach, F., Nyilas, K., Ungar, T., Mackwell, S., and Cordier, P., 2004, Shear deformation experiments of forsterite at $11 \mathrm{GPa}-1400$ degrees $\mathrm{C}$ in the multianvil apparatus. European Journal of Mineralogy, 16, 877-889.

Czertowicz, T.A., Toy, V.G., and Scott, J.M., 2016, Recrystallisation, phase mixing and strain localisation in peridotite during rapid extrusion of sub-arc mantle lithosphere. Journal of Structural Geology, 88, 1-19.

Di Leo, J.F., Walker, A.M., Li, Z.H., Wookey, J., Ribe, N.M., Kendall, J.M., and Tommasi, A., 2014, Development of texture and seismic anisotropy during the onset of subduction. Geochemistry, Geophysics, Geosystems, 15, 192-212.

Di Leo, J.F., Wookey, J., Hammond, J.O.S., Kendall, J.M., Kaneshima, S., Inoue, H., Yamashina, T., and Harjadi, P., 2012, Deformation and mantle flow beneath the Sangihe subduction zone from seismic anisotropy. Physics of the Earth and Planetary Interiors, 194, 38-54.

Díaz Aspiroz, M., Lloyd, G.E., and Fernández, C., 2007, Development of lattice preferred orientation in clinoamphiboles deformed under low-pressure metamorphic conditions. A SEM/EBSD study of metabasites from the Aracena metamorphic belt (SW Spain). Journal of Structural Geology, 29, 629-645.

Faccenda, M., Burlini, L., Gerya, T.V., and Mainprice, D., 2008, Faultinduced seismic anisotropy by hydration in subducting oceanic plates. Nature, 455, 1097-1100.

Faccenda, M. and Capitanio, F.A., 2012, Development of mantle seismic anisotropy during subduction-induced 3-D flow. Geophysical Research Letters, 39, L11305. doi:10.1029/2012GL051988

Faccenda, M. and Capitanio, F.A., 2013, Seismic anisotropy around subduction zones: insights from three-dimensional modeling of upper mantle deformation and SKS splitting calculations. Geochemistry, Geophysics, Geosystems, 14, 243-262.

Fouch, M.J., Fischer, K.M., 1996, Mantle anisotropy beneath northwest Pacific subduction zones. Journal of Geophysical Research: Solid Earth, 101, 15987-16002.

Frese, K., Trommsdorff, V., and Kunze, K., 2003, Olivine [100] normal to foliation: lattice preferred orientation in prograde garnet peridotite formed at high $\mathrm{H}_{2} \mathrm{O}$ activity, Cima di Gagnone (Central Alps). Contributions to Mineralogy and Petrology, 145, 75-86.

Frets, E.C., Tommasi, A., Garrido, C.J., Vauchez, A., Mainprice, D., Targuisti, K., and Amri, I., 2014, The Beni Bousera Peridotite (Rif Belt, Morocco): an oblique-slip low-angle shear zone thinning the sub- 
continental mantle lithosphere. Journal of Petrology, 55, 283-313.

Fumagalli, P. and Poli, S., 2005, Experimentally determined phase relations in hydrous peridotites to $6.5 \mathrm{GPa}$ and their consequences on the dynamics of subduction zones. Journal of Petrology, 46, 555578.

Furukawa, Y., 1993, Magmatic processes under arcs and formation of the volcanic front. Journal of Geophysical Research, 98, 8309-8319.

Gaherty, J.B., 2001, Seismic evidence for hotspot-induced bouyant flow beneath the Peykjanes ridge. Science, 293, 1645-1647.

Getsinger, A.J. and Hirth, G., 2014, Amphibole fabric formation during diffusion creep and the rheology of shear zones. Geology, 42, 535538.

Greve, S.M., Savage, M.K., and Hofmann, S.D., 2008, Strong variations in seismic anisotropy across the Hikurangi subduction zone, North Island, New Zealand. Tectonophysics, 462, 7-21.

Ha, Y., Jung, H., and Raymond, L.A., 2018, Deformation fabrics of glaucophane schists and implications for seismic anisotropy: the importance of lattice preferred orientation of phengite. International Geology Review. DOI 10.1080/00206814.2018.1449142

Hansen, L., Zimmerman, M., and Kohlstedt, D., 2012, Laboratory measurements of the viscous anisotropy of olivine aggregates. Nature, 492, 415-418.

Hansen, L.N. and Warren, J.M., 2015, Quantifying the effect of pyroxene on deformation of peridotite in a natural shear zone. Journal of Geophysical Research: Solid Earth, 120, 2717-2738.

Hansen, L.N., Zhao, Y.-H., Zimmerman, M.E., and Kohlstedt, D.L., 2014, Protracted fabric evolution in olivine: implications for the relationship among strain, crystallographic fabric, and seismic anisotropy. Earth and Planetary Science Letters, 387, 157-168.

Healy, D., Reddy, S.M., Timms, N.E., Gray, E.M., and Brovarone, A.V., 2009, Trench-parallel fast axes of seismic anisotropy due to fluidfilled cracks in subducting slabs. Earth and Planetary Science Letters, $283,75-86$.

Hearmon, R., 1984, The elastic constants of crystals and other anisotropic materials. In: Hellwege K.H. (ed.), Landolt-Bornstein Tables, III/18. Springer-Verlag, Berlin, p. 1-154.

Hess, H.H., 1964, Seismic anisotropy of the uppermost mantle under oceans. Nature, 203, 629-631.

Hidas, K., Falus, G., Szabo, C., Szabo, P.J., Kovacs, I., and Foldes, T., 2007, Geodynamic implications of flattened tabular equigranular textured peridotites from the Bakony-Balaton Highland Volcanic Field (Western Hungary). Journal of Geodynamics, 43, 484-503.

Hirauchi, K., Michibayashi, K., Ueda, H., and Katayama, I., 2010, Spatial variations in antigorite fabric across a serpentinite subduction channel: insights from the Ohmachi Seamount, Izu-Bonin frontal arc. Earth and Planetary Science Letters, 299, 196-206.

Hirth, G. and Kohlstedt, D.L., 1996, Water in the oceanic upper mantle: implications for rheology, melt extraction and the evolution of the lithosphere. Earth and Planetary Science Letters, 144, 93-108.

Holtzman, B.K., Kohlstedt, D.L., Zimmerman, M.E., Heidelbach, F., Hiraga, T., and Hustoft, J., 2003, Melt segregation and strain partitioning: implications for seismic anisotropy and mantle flow. Science, 301, 1227-1230.

Imon, R., Okudaira, T., and Kanagawa, K., 2004, Development of shapeand lattice-preferred orientations of amphibole grains during ini- tial cataclastic deformation and subsequent deformation by dissolution-precipitation creep in amphibolites from the Ryoke metamorphic belt, SW Japan. Journal of Structural Geology, 26, 793-805.

Ishii, K. and Sawaguchi, T., 2002, Lattice- and shape-preferred orientation of orthopyroxene porphyroclasts in peridotites: an application of two-dimensional numerical modeling. Journal of Structural Geology, 24, 517-530.

Jamtveit, B., Brooker, R., Brooks, K., Larsen, L.M., and Pedersen, T., 2001, The water content of olivines from the North Atlantic Volcanic Province. Earth and Planetary Science Letters, 186, 401-415.

Ji, S., Shao, T., Michibayashi, K., Long, C., Wang, Q., Kondo, Y., Zhao, W., Wang, H., and Salisbury, M.H., 2013, A new calibration of seismic velocities, anisotropy, fabrics, and elastic moduli of amphibole-rich rocks. Journal of Geophysical Research: Solid Earth, 118, 46994728.

Ji, S., Shao, T., Michibayashi, K., Oya, S., Satsukawa, T., Wang, Q., Zhao, W., and Salisbury, M.H., 2015, Magnitude and symmetry of seismic anisotropy in mica- and amphibole-bearing metamorphic rocks and implications for tectonic interpretation of seismic data from the southeast Tibetan Plateau. Journal of Geophysical Research: Solid Earth, 120, 6404-6430.

Jung, H., 2009, Deformation fabrics of olivine in Val Malenco peridotite found in Italy and implications for the seismic anisotropy in the upper mantle. Lithos, 109, 341-349.

Jung, H., 2011, Seismic anisotropy produced by serpentine in mantle wedge. Earth and Planetary Science Letters, 307, 535-543.

Jung, H., 2012, Rock deformation and formation of LPO of minerals in the upper mantle: implications for seismic anisotropy. Journal of Petrological Society of Korea, 21, 229-241. (in Korean with English abstract)

Jung, H., Jung, S., Ko, B., and Lee, J., 2014a, Crystal preferred orientation of amphibolites found at Yeoncheon and Chuncheon area in South Korea. Proceedings of the Joint Conference of the Geological Science and Technology of Korea, Busan, Apr. 20-23, p. 146147.

Jung, H. and Karato, S., 2001, Water-induced fabric transitions in olivine. Science, 293, 1460-1463.

Jung, H., Katayama, I., Jiang, Z., Hiraga, T., and Karato, S., 2006, Effect of water and stress on the lattice-preferred orientation of olivine. Tectonophysics, 421, 1-22.

Jung, H., Lee, J., Ko, B., Jung, S., Park, M., Cao, Y., and Song, S., 2013, Natural Type-C olivine fabrics in garnet peridotites in North Qaidam UHP collision belt, NW China. Tectonophysics, 594, 91-102.

Jung, H., Mo, W., and Choi, S.H., 2009a, Deformation microstructures of olivine in peridotite from Spitsbergen, Svalbard and implications for seismic anisotropy. Journal of Metamorphic Geology, 27, 707720.

Jung, H., Mo, W., and Green, H.W., 2009b, Upper mantle seismic anisotropy resulting from pressure-induced slip transition in olivine. Nature Geoscience, 2, 73-77.

Jung, H., Park, M., Jung, S., and Lee, J., 2010, Lattice preferred orientation, water content, and seismic anisotropy of orthopyroxene. Journal of Earth Science, 21, 555-568.

Jung, S., Jung, H., and Austrheim, H., 2014b, Characterization of olivine fabrics and mylonite in the presence of fluid and implications 
for seismic anisotropy and shear localization. Earth, Planets and Space, 66, 41-21.

Kaczmarek, M.-A. and Tommasi, A., 2011, Anatomy of an extensional shear zone in the mantle, Lanzo massif, Italy. Geochemistry, Geophysics, Geosystems, 12, Q0AG06. doi:10.1029/2011GC003627

Kaminski, E. and Ribe, N.M., 2001, A kinematic model for recrystallization and texture development in olivine polycrystals. Earth and Planetary Science Letters, 189, 253-267.

Kaminski, E. and Ribe, N.M., 2002, Timescales for the evolution of seismic anisotropy in mantle flow. Geochemistry, Geophysics, Geosystems, 3. doi:10.1029/2001GC000222

Kaminski, E., Ribe, N.M., and Browaeys, J.T., 2004, D-Rex, a program for calculation of seismic anisotropy due to crystal lattice preferred orientation in the convective upper mantle. Geophysical Journal International, 158, 744-752.

Karato, S., Jung, H., Katayama, I., and Skemer, P., 2008, Geodynamic significance of seismic anisotropy of the upper mantle: new insights from laboratory studies. Annual Review of Earth and Planetary Sciences, 36, 59-95.

Katayama, I., Hirauchi, H., Michibayashi, K., and Ando, J., 2009, Trench-parallel anisotropy produced by serpentine deformation in the hydrated mantle wedge. Nature, 461, 1114-1118.

Katayama, I., Jung, H., and Karato, S.I., 2004, New type of olivine fabric from deformation experiments at modest water content and low stress. Geology, 32, 1045-1048.

Katayama, I. and Karato, S., 2006, Effect of temperature on the B- to Ctype olivine fabric transition and implication for flow pattern in subduction zones. Physics of the Earth and Planetary Interiors, $157,33-45$.

Kim, D. and Jung, H., 2015, Deformation microstructures of olivine and chlorite in chlorite peridotites from Almklovdalen in the Western Gneiss Region, southwest Norway, and implications for seismic anisotropy. International Geology Review, 57, 650-668.

Kim, D., Katayama, I., Michibayashi, K., and Tsujimori, T., 2013, Deformation fabrics of natural blueschists and implications for seismic anisotropy in subducting oceanic crust. Physics of the Earth and Planetary Interiors, 222, 8-21.

Kim, D., Wallis, S., Endo, S., and Ree, J.-H., 2016, Seismic properties of lawsonite eclogites from the southern Motagua fault zone, Guatemala. Tectonophysics, 677, 88-98.

Kitamura, K., 2006, Constraint of lattice-preferred orientation (LPO) on Vp anisotropy of amphibole-rich rocks. Geophysical Journal International, 165, 1058-1065.

Kneller, E.A. and van Keken, P.E., 2007, Trench-parallel flow and seismic anisotropy in the Mariana and Andean subduction systems. Nature, 450, 1222-1225.

Kneller, E.A., van Keken, P.E., Karato, S., and Park, J., 2005, B-type olivine fabric in the mantle wedge: insights from high-resolution nonNewtonian subduction zone models. Earth and Planetary Science Letters, 237, 781-797.

Ko, B. and Jung, H., 2015, Crystal preferred orientation of an amphibole experimentally deformed by simple shear. Nature Communications, 6, 6586. doi:10.1038/ncomms7586

Lamarque, G., Bascou, J., Maurice, C., Cottin, J.-Y., Riel, N., Riel, and Ménot, R.-P., 2016, Microstructures, deformation mechanisms and seismic properties of a Palaeoproterozoic shear zone: the Mertz shear zone, East-Antarctica. Tectonophysics, 680, 174-191.

Lee, J. and Jung, H., 2015, Lattice-preferred orientation of olivine found in diamond-bearing garnet peridotites in Finsch, South Africa and implications for seismic anisotropy. Journal of Structural Geology, $70,12-22$.

Li, Z.-H., Di Leo, J.F., and Ribe, N.M., 2014, Subduction-induced mantle flow, finite strain, and seismic anisotropy: numerical modeling. Journal of Geophysical Research: Solid Earth, 119, 5052-5076.

Linckens, J., Herwegh, M., Muntener, O., and Mercolli, I., 2011, Evolution of a polymineralic mantle shear zone and the role of second phases in the localization of deformation. Journal of Geophysical Research: Solid Earth, 116, B06210. doi:10.1029/2010JB008119

Llana-Fúnez, S. and Brown, D., 2012, Contribution of crystallographic preferred orientation to seismic anisotropy across a surface analog of the continental Moho at Cabo Ortegal, Spain. Geological Society of America Bulletin, 124, 1495-1513.

Lloyd, G.E., Butler, R.W.H., Casey, M., Tatham, D.J., and Mainprice, D., 2011, Constraints on the seismic properties of the middle and lower continental crust. Geological Society of London, Special Publication, 360, 7-32.

Long, M.D., 2013, Constraints on subduction geodynamics from seismic anisotropy. Reviews of Geophysics, 51, 76-112.

Long, M.D. and Becker, T.W., 2010, Mantle dynamics and seismic anisotropy. Earth and Planetary Science Letters, 297, 341-354.

Long, M.D. and Silver, P.G., 2008, The subduction zone flow field from seismic anisotropy: a global view. Science, 319, 315-318.

Long, M.D. and Silver, P.G., 2009, Shear wave splitting and mantle anisotropy: measurements, interpretations, and new directions. Surveys in Geophysics, 30, 407-461.

Long, M.D. and van der Hilst, R.D., 2005, Upper mantle anisotropy beneath Japan from shear wave splitting. Physics of the Earth and Planetary Interiors, 151, 206-222.

Long, M.D. and Wirth, E.A., 2013, Mantle flow in subduction systems: the mantle wedge flow field and implications for wedge processes. Journal of Geophysical Research: Solid Earth, 118, 583-606.

Lynner, C. and Long, M.D., 2014, Sub-slab anisotropy beneath the Sumatra and circum-Pacific subduction zones from source-side shear wave splitting observations. Geochemistry, Geophysics, Geosystems, 15, 2262-2281.

Lynner, C., Long, M.D., Tissen, C.J., Paczkowski, K., and Montesi, L.G.J., 2017, Evaluating geodynamic models for sub-slab anisotropy: effects of olivine fabric type. Geological Society of America Bulletin, 13, 247-259.

Mackwell, S.J. and Kohlstedt, D.L., 1990, Diffusion of hydrogen in olivine - implications for water in the mantle. Journal of Geophysical Research: Solid Earth and Planets, 95, 5079-5088.

Mainprice, D., 2007, Seismic anisotropy of the deep Earth from a mineral and rock physics perspective, treatise on geophysics. In: Schubert, G. (ed.), Treatise in Geophysics - Volume 2: Mineral Physics. Elsevier, Amsterdam, p. 437-491.

Mainprice, D., Barruol, G., and Ismail, W.B., 2000, The seismic anisotropy of the earth's mantle from single crystal to polycrystal. In: Karato, S., Forte, A.M., Liebermann, R.C., Masters, G., and Stixrude, L. (eds.), Earth's Deep Interior. American Geophysical Union, 
Geophysical Monograph, 117, p. 237-264.

Mainprice, D. and Ildefonse, B., 2009, Seismic anisotropy of subduction zone minerals - contribution of hydrous phases. In: Lallemand, S. and Funiciello, F. (eds.), Subduction Zone Geodynamics, Frontiers in Earth Sciences. Springer-Verlag, Berlin, p. 63-84.

Mainprice, D. and Nicolas, A., 1989, Development of shape and lattice preferred orientations: application to the seismic anisotropy of the lower crust. Journal of Structural Geology, 11, 175-189.

Mainprice, D. and Silver, P.G., 1993, Interpretation of SKS-waves using samples from the subcontinental lithosphere. Physics of the Earth and Planetary Interiors, 78, 257-280.

Manthilake, M.A.G.M., Miyajima, N., Heidelbach, F., Soustelle, V., and Frost, D.J., 2013, The effect of aluminum and water on the development of deformation fabrics of orthopyroxene. Contributions to Mineralogy and Petrology, 165, 495-505.

Margheriti, L., Nostro, C., Cocco, M., and Amato, A., 1996, Seismic anisotropy beneath the Northern Apennines (Italy) and its tectonic implications. Geophysical Research Letters, 23, 2721-2724.

Mercier, J.C., 1985, Olivine and pyroxene. In: Wenk, H.R. (ed.), Preferred Orientation in Deformed Metals and Rocks: An Introduction to Modern Texture Analysis. Academic Press, New York, p. 407-430.

Michibayashi, K., Ina, T., and Kanagawa, K., 2006, The effect of dynamic recrystallization on olivine fabric and seismic anisotropy: insight from a ductile shear zone, Oman ophiolite. Earth and Planetary Science Letters, 244, 695-708.

Michibayashi, K., Kusafuka, Y., Satsukawa, T., and Nasir, S.J., 2012, Seismic properties of peridotite xenoliths as a clue to imaging the lithospheric mantle beneath NE Tasmania, Australia. Tectonophysics, 522-523, 218-223.

Michibayashi, K., Mainprice, D., Fujii, A., Uehara, S., Shinkai, Y., Kondo, Y., Ohara, Y., Ishii, T., Fryer, P., Bloomer, S.H., Ishiwatari, A., Hawkins, J.W., and Ji, S., 2016, Natural olivine crystal-fabrics in the western Pacific convergence region: a new method to identify fabric type. Earth and Planetary Science Letters, 443, 70-80.

Michibayashi, K. and Oohara, T., 2013, Olivine fabric evolution in a hydrated ductile shear zone at the Moho Transition Zone, Oman Ophiolite. Earth and Planetary Science Letters, 377-378, 299-310.

Michibayashi, K., Tasaka, M., Ohara, Y., Ishii, T., Okamoto, A., and Fryer, P., 2007, Variable microstructure of peridotite samples from the southern Mariana Trench: evidence of a complex tectonic evolution. Tectonophysics, 444, 111-118.

Miyazaki, T., Sueyoshi, K., and Hiraga, T., 2013, Olivine crystals align during diffusion creep of Earth's upper mantle. Nature, 502, 321326.

Mizukami, T., Wallis, S.R., and Yamamoto, J., 2004, Natural examples of olivine lattice preferred orientation patterns with a flow-normal aaxis maximum. Nature, 427, 432-436.

Montagner, J.P. and Guillot, L., 2000, Seismic anisotropy in the Earth's mantle. In: Boschi, E., Dziewonski, A.M., Morelli, A., and Ekström, G. (eds.), Problems in Geophysics for the New Millennium. Compositori, Bologna, p. 213-253.

Mookherjee, M. and Mainprice, D., 2014, Unusually large shear wave anisotropy for chlorite in subduction zone settings. Geophysical Research Letters, 41, 1506-1513.
Morales, L.F., Mainprice, D., and Boudier, F., 2013, The influence of hydrous phases on the microstructure and seismic properties of a hydrated mantle rock. Tectonophysics, 594, 103-117.

Müller, C., Bayer, B., Eckstaller, A., and Miller, H., 2008, Mantle flow in the South Sandwich subduction environment from source-side shear wave splitting. Geophysical Research Letters, 35, L03301. doi:10.1029/2007GL032411

Nagaya, T., Walker, A.M., Wookey, J., Wallis, S.R., Ishii, K., and Kendall, J.M., 2016, Seismic evidence for flow in the hydrated mantle wedge of the Ryukyu subduction zone. Scientific Reports, 6, 29981. doi:10.1038/srep29981

Nagaya, T., Wallis, S.R., Kobayashi, H., Michibayashi, K., Mizukami, T., Seto, Y., Miyake, A., and Matsumoto, M., 2014, Dehydration breakdown of antigorite and the formation of B-type olivine CPO. Earth and Planetary Science Letters, 387, 67-76.

Nakajima, J. and Hasegawa, A., 2004, Shear-wave polarization anisotropy and subduction-induced flow in the mantle wedge of northeastern Japan. Earth and Planetary Science Letters, 225, 365-377.

Nicolas, A. and Christensen, N.I., 1987, Formation of anisotropy in upper mantle peridotites: a review. American Geophysical Union, 16, 111123.

Nishii, A., Wallis, S.R., Mizukami, T., and Michibayashi, K., 2011, Subduction related antigorite $\mathrm{CPO}$ patterns from forearc mantle in the Sanbagawa belt, southwest Japan. Journal of Structural Geology, 33, 1436-1445.

Ohuchi, T. and Irifune, T., 2013, Development of A-type olivine fabric in water-rich deep upper mantle. Earth and Planetary Science Letters, 362, 20-30.

Ohuchi, T. and Irifune, T., 2014, Crystallographic preferred orientation of olivine in the Earth's deep upper mantle. Physics of the Earth and Planetary Interiors, 228, 220-231.

Ohuchi, T., Kawazoe, T., Nishihara, Y., Nishiyama, N., and Irifune, T., 2011, High pressure and temperature fabric transitions in olivine and variations in upper mantle seismic anisotropy. Earth and Planetary Science Letters, 304, 55-63.

Ohuchi, T., Nishihara, Y., Seto, Y., Kawazoe, T., Nishi, M., Maruyama, G., Hashimoto, M., Higo, Y., Funakoshi, K.-I., Suzuki, A., Kikegawa, T., and Irifune, T., 2015, In situ observation of crystallographic preferred orientation of deforming olivine at high pressure and high temperature. Physics of the Earth and Planetary Interiors, 243, 1-21.

Padrón-Navarta, J.A., Tommasi, A., Garrido, C.J., and Mainprice, D., 2015, On topotaxy and compaction during antigorite and chlorite dehydration: an experimental and natural study. Contributions to Mineralogy and Petrology, 169, 35.

Park, J. and Levin, V., 2002, Seismic anisotropy: tracing plate dynamics in the mantle. Science, 296, 485-489.

Park, M. and Jung, H., 2017, Microstructural evolution of the Yugu peridotites in the Gyeonggi Massif, Korea: implications for olivine fabric transition in mantle shear zones. Tectonophysics, 709, 55-68.

Park, M., Jung, H., and Kil, Y., 2014, Petrofabrics of olivine in a rift axis and rift shoulder and their implications for seismic anisotropy beneath the Rio Grande rift. Island Arc, 23, 299-311.

Park, Y. and Jung, H., 2015, Deformation microstructures of olivine and pyroxene in mantle xenoliths in Shanwang, eastern China, near the convergent plate margin, and implications for seismic anisotropy. 
International Geology Review, 57, 629-649.

Pawley, A., 2003, Chlorite stability in mantle peridotite: the reaction clinochlore + enstatite $=$ forsterite + pyrope $+\mathrm{H}_{2} \mathrm{O}$. Contributions to Mineralogy and Petrology, 144, 449-456.

Peacock, S.M. and Hyndman, R.D., 1999, Hydrous minerals in the mantle wedge and the maximum depth of subduction thrust earthquakes. Geophysical Research Letters, 26, 2517-2520.

Precigout, J. and Hirth, G., 2014, B-type olivine fabric induced by grain boundary sliding. Earth and Planetary Science Letters, 395, 231240.

Précigout, J., Prigent, C., Palasse, L., and Pochon, A., 2017, Water pumping in mantle shear zones. Nature Communications, 8, 15736. doi:10.1038/ ncomms15736

Puelles, P., Ábalos, B., Gil Ibarguchi, J.I., Sarrionandia, F., Carracedo, M., and Fernández-Armas, S., 2016, Petrofabric and seismic properties of lithospheric mantle xenoliths from the Calatrava volcanic field (Central Spain). Tectonophysics, 683, 200-215.

Puelles, P., Gil Ibarguchi, J.I., Beranoaguirre, A., and Ábalos, B., 2012, Mantle wedge deformation recorded by high-temperature peridotite fabric superposition and hydrous retrogression (Limo massif, Cabo Ortegal, NW Spain). International Journal of Earth Sciences, 101, 1835-1853.

Raleigh, C.B., 1965, Glide mechanisms in experimentally deformed minerals. Science, 150, 739-741.

Raleigh, C.B., 1968, Mechanisms of plastic deformation of olivine. Journal of Geophysical Research, 73, 5391-5406.

Ringwood, A.E., 1970, Phase transformations and the constutution of the mantle. Physics of the Earth and Planetary Interiors, 3, 109-155.

Russo, R.M. and Silver, P.G., 1994, Trench-parallel flow beneath the Nazca plate from seismic anisotropy. Science, 263, 1105-1111.

Savage, M.K., 1999, Seismic anisotropy and mantle deformation: what have we learned from shear wave splitting? Reviews of Geophysics, 37, 65-106.

Schmidt, M.W. and Poli, S., 1998, Experimentally based water budgets for dehydrating slabs and consequences for arc magma generation. Earth and Planetary Science Letters, 163, 361-379.

Schwerdtner, W.M., 1964, Preferred orientation of hornblende in a banded hornblende gneiss. American Journal of Science, 262, 12121229.

Siegesmund, S., Takeshita, T., and Kern, H., 1989, Anisotropy of Vp and Vs in an amphibolite of the deeper crust and its relationship to the mineralogical, microstructural and textural characteristics of the rock. Tectonophysics, 157, 25-38.

Siegesmund, S. and Vollbrecht, A., 1991, Complete seismic properties obtained from microcrack fabrics and textures in an amphibolite from the Ivrea zone, Western Alps, Italy. Tectonophysics, 199, 13-24.

Signorelli, J. and Tommasi, A., 2015, Modeling the effect of subgrain rotation recrystallization on the evolution of olivine crystal preferred orientations in simple shear. Earth and Planetary Science Letters, 430, 356-366.

Silver, P.G., 1996, Seismic anisotropy beneath the continents: probing the depths of geology. Annual Review of Earth and Planetary Sciences, 24, 385 .

Silver, P.G. and Chan, W.W., 1991, Shear-wave splitting and subcontinental mantle deformation. Journal of Geophysical Research: Solid
Earth, 96, 16429-16454.

Skemer, P. and Hansen, L.N., 2016, Inferring upper-mantle flow from seismic anisotropy: an experimental perspective. Tectonophysics, 668, 1-14.

Skemer, P., Katayama, I., and Karato, S.I., 2006, Deformation fabrics of the Cima di Gagnone peridotite massif, Central Alps, Switzerland: evidence of deformation at low temperatures in the presence of water. Contributions to Mineralogy and Petrology, 152, 43-51.

Skemer, P., Warren, J.M., Hansen, L.N., Hirth, G., and Kelemen, P.B., 2013, The influence of water and LPO on the initiation and evolution of mantle shear zones. Earth and Planetary Science Letters, $375,222-233$.

Skemer, P., Warren, J.M., Kelemen, P.B., and Hirth, G., 2010, Microstructural and rheological evolution of a mantle shear zone. Journal of Petrology, 51, 43-53.

Smith, G.P., Wiens, D.A., Fischer, K.M., Dorman, L.M., Webb, S.C., and Hildebrand, J.A., 2001, A complex pattern of mantle flow in the Lau backarc. Science, 292, 713-716.

Soda, Y. and Takagi, H., 2010, Sequential deformation from serpentinite mylonite to metasomatic rocks along the Sashu fault, SW Japan. Journal of Structural Geology, 32, 792-802.

Song, T.-R.A. and Kawakatsu, H., 2012, Subduction of oceanic asthenosphere: evidence from sub-slab seismic anisotropy. Geophysical Research Letters, 39, L17301. doi:10.1029/2012GL052639

Song, T.-R.A. and Kawakatsu, H., 2013, Subduction of oceanic asthenosphere: a critical appraisal in central Alaska. Earth and Planetary Science Letters, 367, 82-94.

Soustelle, V. and Manthilake, G., 2017, Deformation of olivine-orthopyroxene aggregates at high pressure and temperature: implications for the seismic properties of the asthenosphere. Tectonophysics, 694, 385-399.

Soustelle, V., Tommasi, A., Demouchy, S., and Ionov, D.A., 2009, Deformation and fluid-rock interaction in the supra-subduction mantle: microstructures and water contents in peridotite xenoliths from the Avacha volcano, Kamchatka. Journal of Petrology, 51, 363-394.

Sundberg, M. and Cooper, R.F., 2008, Crystallographic preferred orientation produced by diffusional creep of harzburgite: effects of chemical interactions among phases during plastic flow. Journal of Geophysical Research: Solid Earth, 113, B12208. doi:10.1029/ 2008JB005618

Tasaka, M., Michibayashi, K., and Mainprice, D., 2008, B-type olivine fabrics developed in the fore-arc side of the mantle wedge along a subducting slab. Earth and Planetary Science Letters, 272, 747-757.

Tatham, D.J., Lloyd, G.E., Butler, R.W.H., and Casey, M., 2008, Amphibole and lower crustal seismic properties. Earth and Planetary Science Letters, 267, 118-128.

Tommasi, A., Mainprice, D., Canova, G., and Chastel, Y., 2000, Viscoplastic self-consistent and equilibrium-based modeling of olivine lattice preferred orientations: implications for the upper mantle seismic anisotropy. Journal of Geophysical Research: Solid Earth, 105, 7893-7908.

Tommasi, A. and Vauchez, A., 2015, Heterogeneity and anisotropy in the lithospheric mantle. Tectonophysics, 661, 11-37.

Tommasi, A., Vauchez, A., and Ionov, D.A., 2008, Deformation, static recrystallization, and reactive melt transport in shallow subconti- 
nental mantle xenoliths (Tok Cenozoic volcanic field, SE Siberia). Earth and Planetary Science Letters, 272, 65-77.

Ulmer, P. and Trommsdorff, V., 1995, Serpentine stability to mantle depths and subduction-related magmatism. Science, 268, 858-861.

van Keken, P.E., Hacker, B.R., Syracuse, E.M., and Abers, G.A., 2011, Subduction factory: 4. Depth-dependent flux of $\mathrm{H}_{2} \mathrm{O}$ from subducting slabs worldwide. Journal of Geophysical Research: Solid Earth, 116, B01401. doi:10.1029/2010JB007922

Verma, R.K., 1960, Elasticity of some high-density crystals. Journal of Geophysical Research, 65, 757-766.

Wagner, L.S., Fouch, M.J., James, D.E., and Long, M.D., 2013, The role of hydrous phases in the formation of trench parallel anisotropy: evidence from Rayleigh waves in Cascadia. Geophysical Research Letters, 40, 2642-2646.

Wallace, P.J., 1998, Water and partial melting in mantle plumes: inferences from the dissolved $\mathrm{H}_{2} \mathrm{O}$ concentrations of Hawaiian basaltic magmas. Geophysical Research Letters, 25, 3639-3642.

Wallis, D., Lloyd, G.E., Phillips, R.J., Parsons, A.J., and Walshaw, R.D., 2015, Low effective fault strength due to frictional-viscous flow in phyllonites, Karakoram Fault Zone, NW India. Journal of Structural Geology, 77, 45-61.

Wang, J. and Zhao, D., 2013, P-wave tomography for 3-D radial and azimuthal anisotropy of Tohoku and Kyushu subduction zones. Geophysical Journal International, 193, 1166-1181.

Wang, Q., Xia, Q.K., O'Reilly, S.Y., Griffin, W.L., Beyer, E.E., and Brueckner, H.K., 2013a, Pressure- and stress-induced fabric transition in olivine from peridotites in the Western Gneiss Region (Norway): implications for mantle seismic anisotropy. Journal of Metamorphic Geology, 31, 93-111.

Wang, Y., Zhang, J., and Shi, F., 2013b, The origin and geophysical implications of a weak C-type olivine fabric in the Xugou ultrahigh pressure garnet peridotite. Earth and Planetary Science Letters, $376,63-73$.

Warren, J.M., Hirth, G., and Kelemen, P.B., 2008, Evolution of olivine lattice preferred orientation during simple shear in the mantle. Earth and Planetary Science Letters, 272, 501-512.
Watanabe, T., Shirasugi, Y., and Michibayashi, K., 2014, A new method for calculating seismic velocities in rocks containing strongly dimensionally anisotropic mineral grains and its application to antigorite-bearing serpentinite mylonites. Earth and Planetary Science Letters, 391, 24-35.

Webber, C.E., Little, T., Newman, J., and Tikoff, B., 2008, Fabric superposition in upper mantle peridotite, Red Hills, New Zealand. Journal of Structural Geology, 30, 1412-1428.

Weiss, T., Siegesmund, S., Rabbel, W., Bohlen, T., and Pohl, M., 1999, Seismic velocities and anisotropy of the lower continental crust: a review. Pure and Applied Geophysics, 156, 97-122.

Wenk, H.R. and Tomé, C.N., 1999, Modeling dynamic recrystallization of olivine aggregates deformed in simple shear. Journal of Geophysical Research: Solid Earth, 104, 25513-25527.

Xu, Z.Q., Wang, Q., Ji, S.C., Chen, J., Zeng, L.S., Yang, J.S., Chen, F.Y., Liang, F.H., and Wenk, H.R., 2006, Petrofabrics and seismic properties of garnet peridotite from the UHP Sulu terrane (China): implications for olivine deformation mechanism in a cold and dry subducting continental slab. Tectonophysics, 421, 111-127.

Yamamoto, T., Ando, J.-i., Tomioka, N., and Kobayashi, T., 2017, Deformation history of Pinatubo peridotite xenoliths: constraints from microstructural observation and determination of olivine slip systems. Physics and Chemistry of Minerals, 44, 247-262.

Yang, K., Hidas, K., Falus, G., Szabo, C., Nam, B., Kovacs, I., and Hwang, B., 2010, Relation between mantle shear zone deformation and metasomatism in spinel peridotite xenoliths of Jeju Island (South Korea): evidence from olivine $\mathrm{CPO}$ and trace elements. Journal of Geodynamics, 50, 424-440.

Zhang, S.Q. and Karato, S., 1995, Lattice preferred orientation of olivine aggregates deformed in simple shear, Nature, 375, 774-777.

Zhang, S.Q., Karato, S., Fitz Gerald, J.D., Faul, U.H., and Zhou, Y., 2000, Simple shear deformation of olivine aggregates. Tectonophysics, 316, 133-152.

Zhao, D., Yu, S., and Liu, X., 2016, Seismic anisotropy tomography: new insight into subduction dynamics. Gondwana Research, 33, 24-43. 